Historic, Archive Document

Do not assume content reflects current scientific knowledge, policies, or practices. 


\section{Wholesale Price=List}
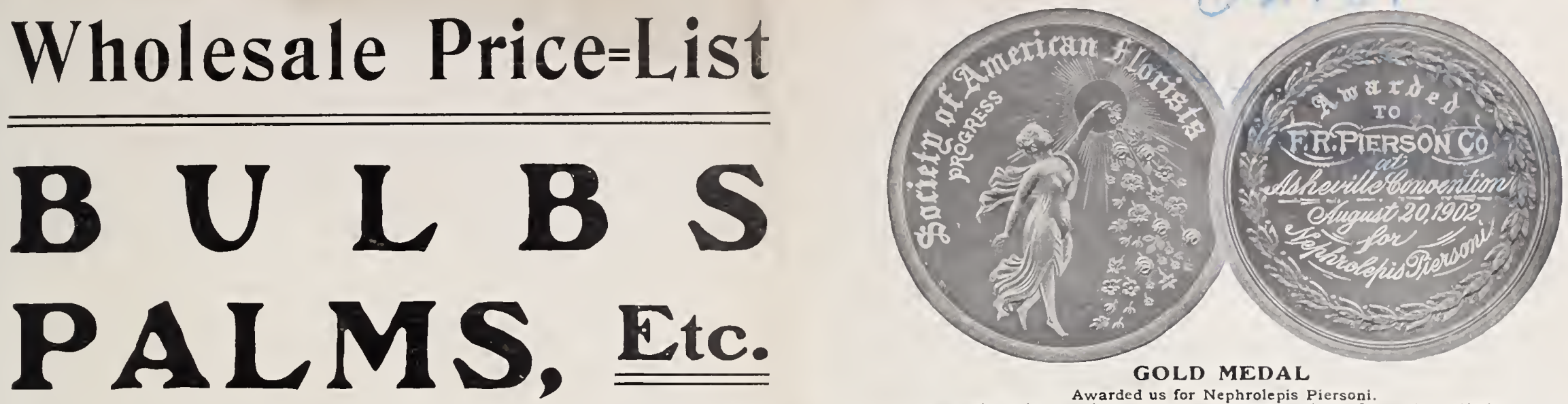

\section{GOLD MEDAL}

The only Gold Medal ever awarded by the Society of American Florists.

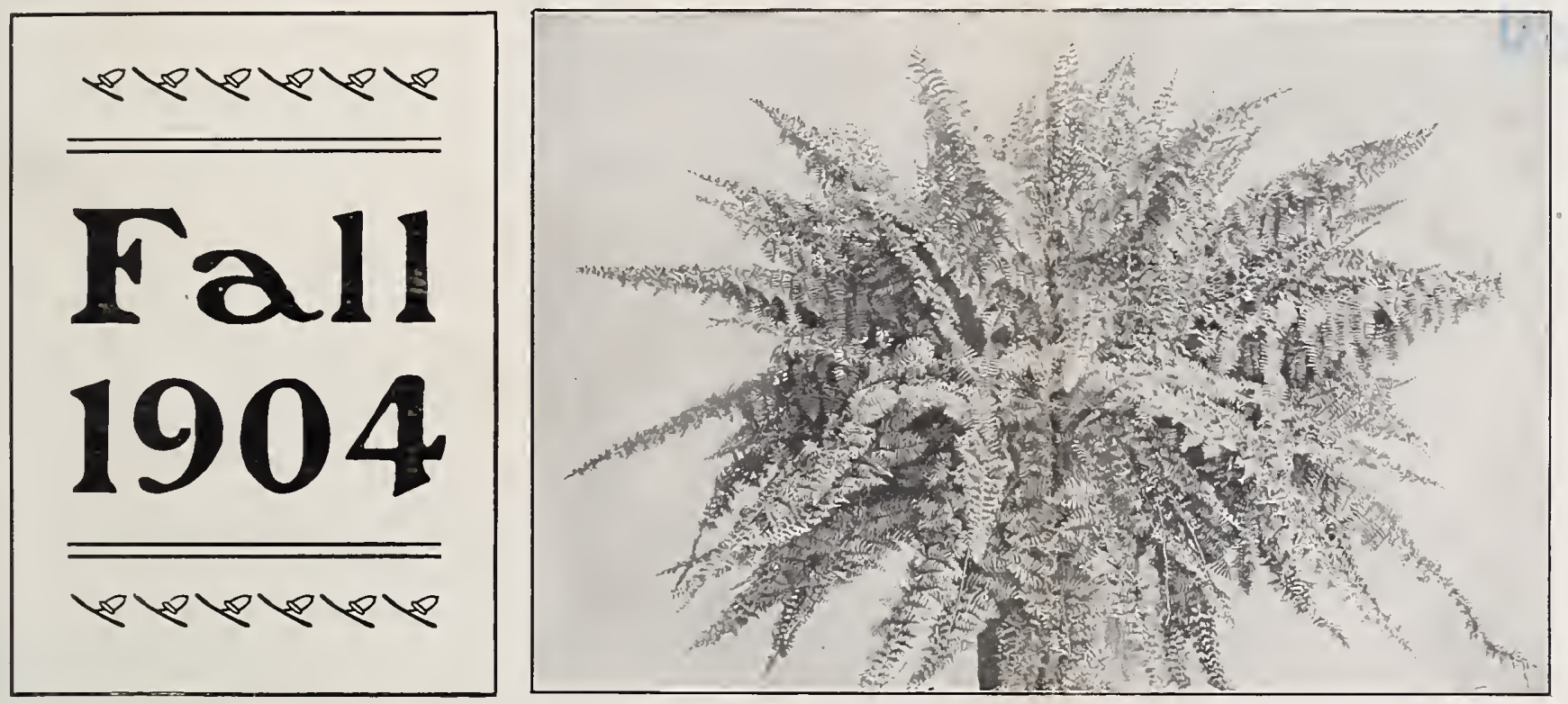

Q

To customers of approved credit 60 days' credit will be given, unless otherwise agreed upon, or 3 per cent. discount for cash within 15 days from date of invoice, or 5 per cent. discount where cash is remitted with order.

All accounts remaining unpaid when due are subject to sight draft without further notice. New customers desirous of opening accounts with us must give satisfactory references as to their responsibility. Prices subject to change without notice.

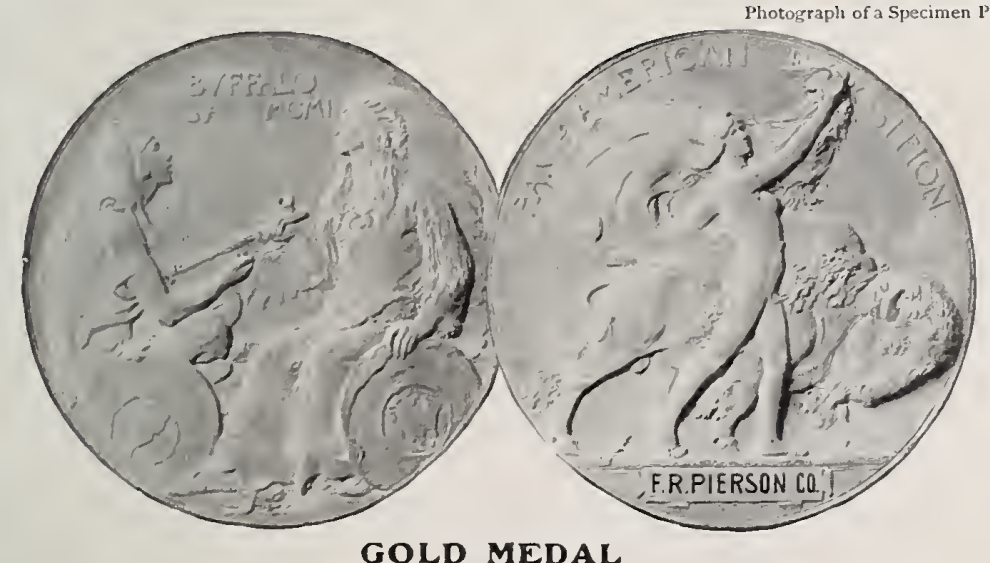

GOLD MEDAL

Highest Award, Pan-American Exposition, rgor.
Awarded us for LARGEST and BEST COLLECTION of BULBS.

\section{T. R. Pierson Co.}

Cable Address, Pierson, Tarrytown (A B C Code used)

Long Distance Telephone, Tarrytown, 48 


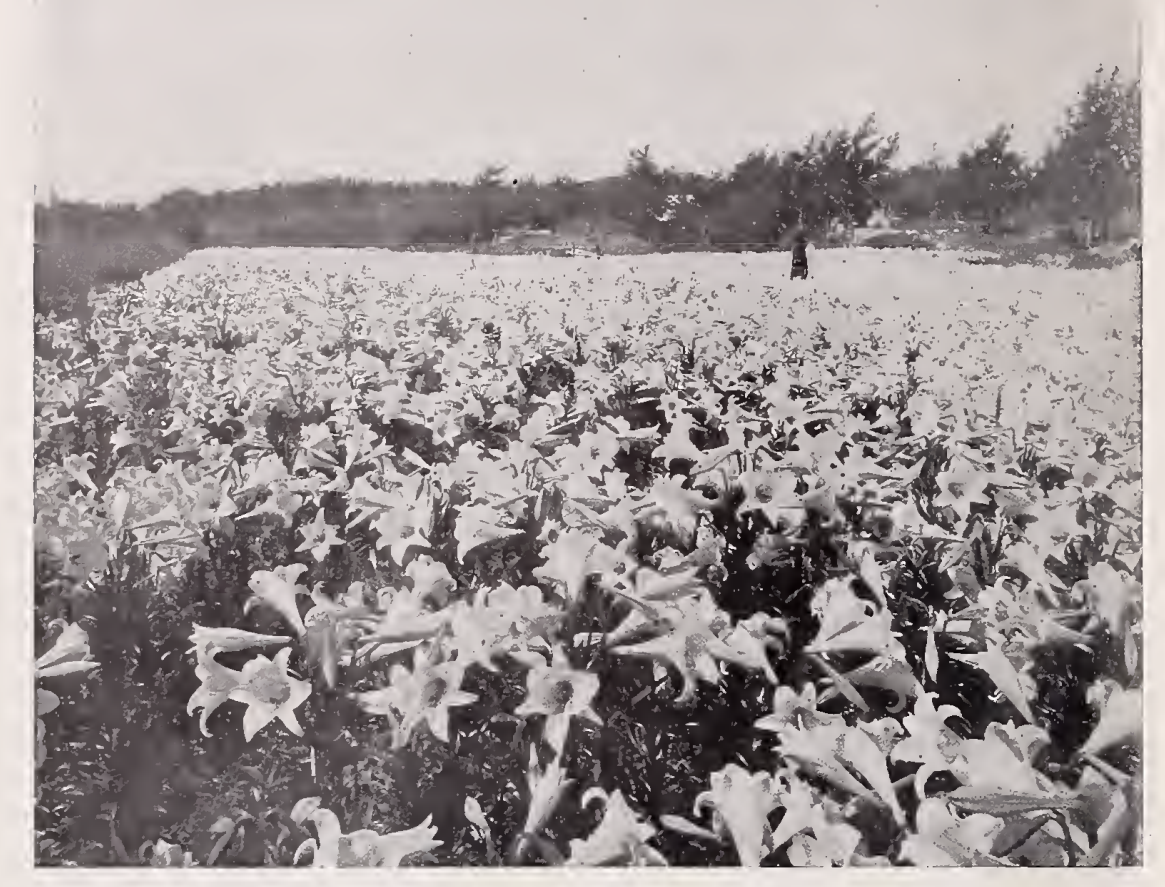

Lilium Harrisii. Now ready for delivery.

Nothing that can be handled is more profitable than Lilium Harrisii when well grown, as the is a good and sure demand for it at all times. We are very particular about the Harrisil that we hand
Our stock is not picked up indiscriminately from small growers, but is grown for us by only a few s. lected growers whose stocks are healthy and free from disease. Our bulbs have never been finer tha:
they are this season. For Christmas-flowering bulbs should be potted as early in August as they can $b$ procured. For this purpose our 6 to 7 -inch size is preterable, as this size can be brought into bloom 65 degrees at night. bulbs, measuring 6 to 7 inches, thus giving a much better grade of bulls than

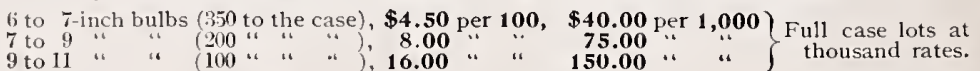

Callas. Now ready for delivery.

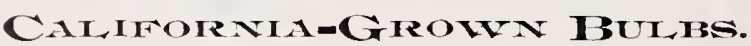

Ourstock will be found to be of very superior quality. Our bulbs are grown for us by one of tire
most careful and experienced growers on the Pacific coast. They are very carefully cured, and are perfectly sound, with good, strong centres-an important consideration. Florists will find that flowered from vear to year-the difference in results being so great that it well repays the seening expense of an outlay for bulbs each year
over old bulbs from year to year.

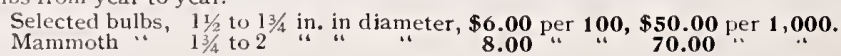

Freesia Refracta Alba. Now ready for Very large quantities of these bulbs are now grown for winter-flowering, as they are very useful and

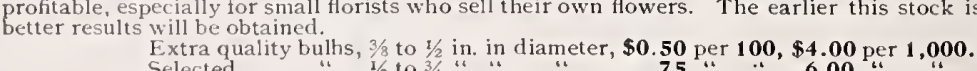

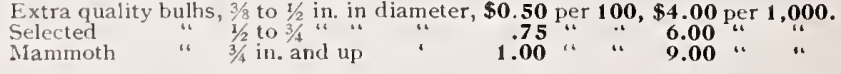

\section{Lilium Longiflorum (Bermuda-grown). \\ Now ready for delivery.} Longiflorum is preferred to Harrisiz by many growers for growing for sale as pot plants for Easter
s the foliage is considetably hearier, forming a more compact and better furnished plant when standing longer season in which to bring them into bloom for Easter, and they are more certain to flower in supplied until October. Those who have had difficulty in getting in the Japan-grown bulbs in time should use the Bermuda-grown bulbs. Large growers who grow whole houses of lilies have no difficult necessary heat and special attention very often have trouble in getting the Japan-grown bulbs in bloon 7 to 9 -inch bulbs (200 to the case), $\$ 8.00$ per $\mathbf{1 0 0}, \$ 75,00$ per 1,000 .

Lilium Longiflorum (Japan-grown). Ready for delivery early in October.

These are being planted very largely by many growers, as they can be the high price of the Bernuda bulbs, and some growers prefer them. We offer very carefully sefecter stock of the very finest Japanese bulbs obtainahle. 7 to 9 -inch bulbs (300 to the case), $\$ \mathbf{4 0 0}$ per $\mathbf{1 0 0}, \mathbf{\$ 4 0 . 0 0}$ per $\mathbf{1 , 0 0 0}$

\section{Lilium Longiflorum Multiflorum.}

This is a selected type, blooming much earlier and flowering more abundantly than the regular typ

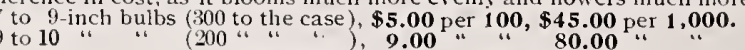

\section{Lilium Longiflorum Giganteum.}

in the flowers are larger and longer and have more substance. It is disting uished by its dark brownish stem. Growers should give this a carefu
test. It should be grown cool until the bulds are set, after which it will stand any amount of forcing. 7 to 9 -inch bulbs (300 to the case), \$ 10.00 per $\mathbf{1 0 0 ,} \$ \mathbf{5 5 . 0 0}$ per $\mathbf{1 , 0 0 0}$.

\section{Lilium Candidum the Annunciation Lily)}

\section{Now ready for delivery}

This is still used for forcing in some localities where it is a favorite. It is also very desirable fo more beautiful in hardy plants, and it should be used largely for is as hardy as can be. There is nothing feet high, bearing large clusters of medium sized flowers, delightfully fragrant. As it starts into frowt very early in the fall, the earlier it is ordered in the fall, the better results will be
Extra selected bulbs, $\$ \mathbf{5 . 0 0}$ per $\mathbf{1 0 0}, \mathbf{\$ 4 0 . 0 0}$ per $\mathbf{1 , 0 0 0}$.

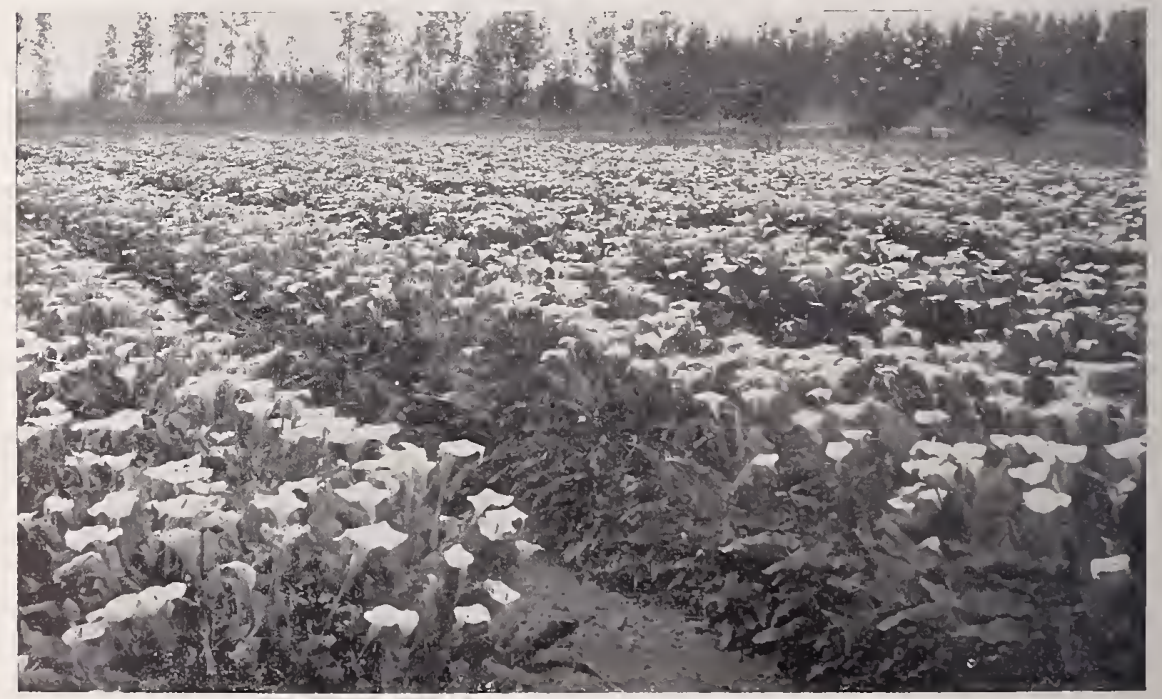




\section{Japan Li!ies}

Lilium Auratum. Bulbs \& to 9 in. in circumference. \$ \$5.00 per $100, \quad \$ \$ 5.00$ per 1,000 .

Lilium Album.-Bulbs s to 9 in. in circumference .

Lilium Melpomene. -Bulbs s to 8 int. in circunference $\mathbf{6 . 0 0}$

Lilium Rubrum. "Bulbs 8 to 9 in in. "in circumference

\begin{tabular}{|c|c|c|c|}
\hline $\begin{array}{l}5.00 \mathrm{I} \\
8.00\end{array}$ & 100 & $\begin{array}{r}\$ 5.00 \\
70.00\end{array}$ & \\
\hline 8.00 & ". & 70.00 & ". \\
\hline $\begin{array}{l}6.00 \\
8.00\end{array}$ & “. & $\begin{array}{l}55.00 \\
75.00\end{array}$ & "4 \\
\hline 6.00 & “ & 55.00 & “" \\
\hline 8.00 & “" & 75.00 & ." \\
\hline
\end{tabular}

\section{Japanese Fern Balls}

Now ready for delivery.

Inported from Japan. One of the finest selling novelties ever introduced. The balls are made of he roots of the long leaved Davallia, olte of the most beautiful Japanese ferns, wonnd orer a lall o placed in in moist, growing temperature, they leaf ont and grow very rapidly, and in a short time are will find a really sale for them at a fine profit.
Extra sized balls (dormant), about 8 in. in diameter. $\$ 3.00$ per doz., $\$ 20.00$ per 100 .

\section{Gladiolus Colvilli Alba "The Bride"}

Ready for delivery in October.

Flowers pure white. Of dwarf habit. Invaluable for forcing and for outdoor blooming. It is being more and more largely planted, as it is one of the most useful cut flowers that can be grown.

\section{Astilbe, or Spirea}

\section{Ready for delivery in November.}

Japonica. - Large imported clumps, grown especially for forcing. $\$ 5.00$ per $100, \$ 10.00$ for Compacta Multiflora. More compact than Japonica; an extra fine variety for forcing. Astilboides Floribunda. A very strong grower, and quite distinct fronl the other two pure white, very large and feathery. $\$ 6.00$ per $100, \$ 12.00$ for case of 250 clumps.

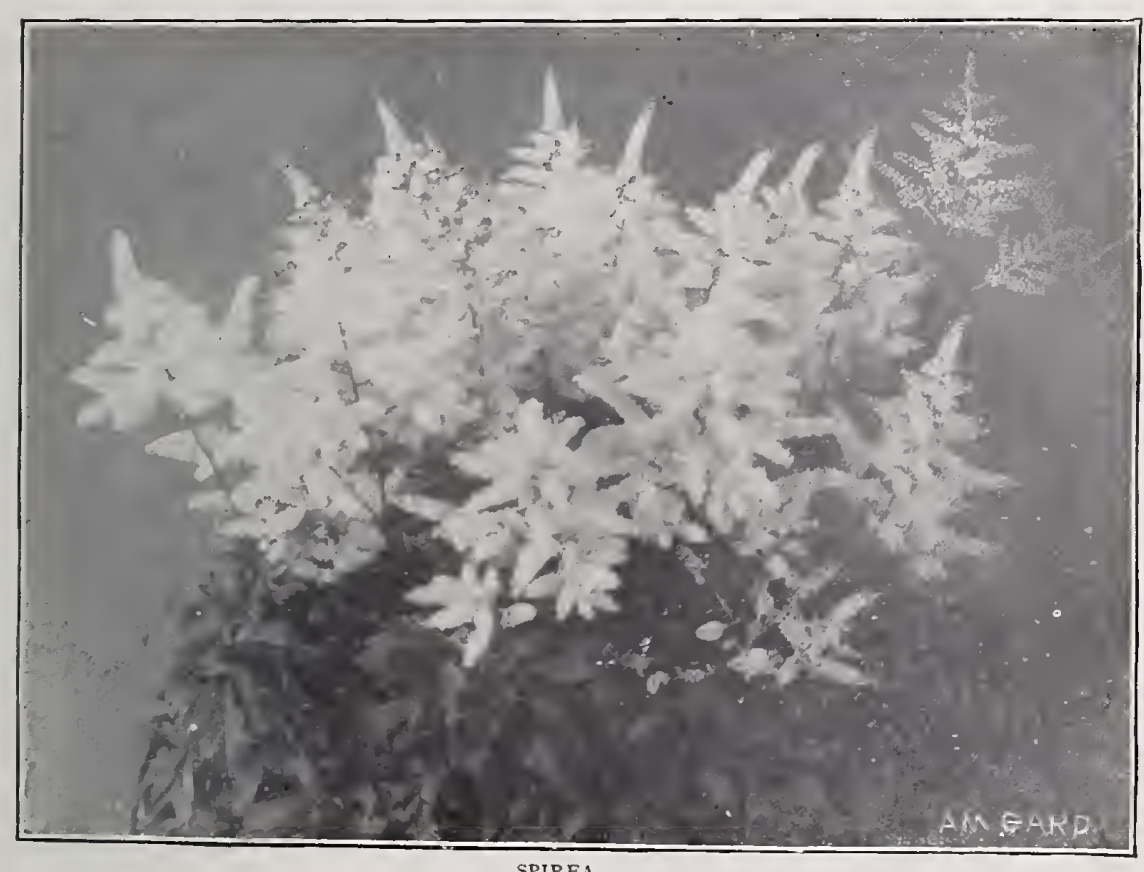

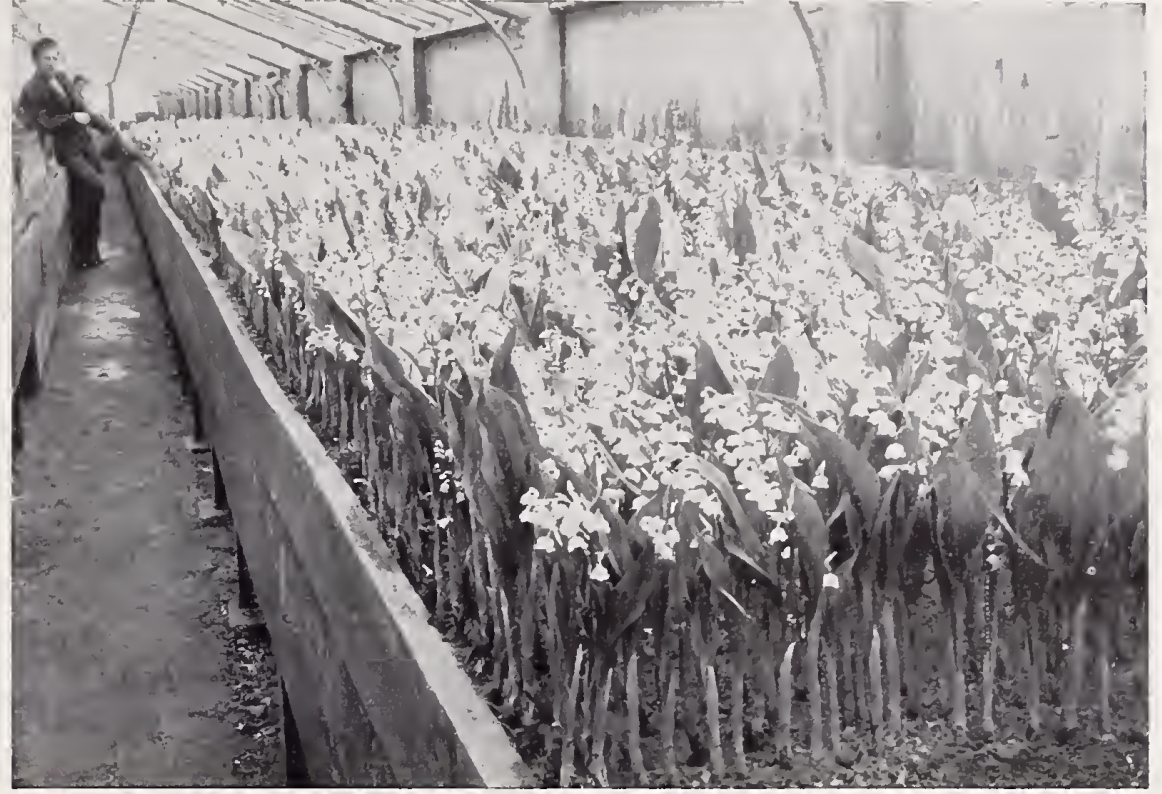

Photograph of a House of our Premier Valley

\section{Lily of the Valley}

Ready for delivery in November.

Pierson's Perfection. - This is an extra selected grade for those who desire the finest forcing. Price of Valley has been driven down so low that it has been at the expense of quality. and growers are beginning to realize that a really first-class article cannot be furnished at prices and St. Petersburg to growers who have been willing to pay the price for a vcry superior article, and very few, if any, of the finest pips grown have reached this country; but there is beginning to be a demand here for a better grade of Valley than is generally offered, and in order to ineet this clemand, we a re importing this grade of pips, which we have had selected for us with great care, and which are the very finest pips grown. They will produce the largest spikes, with the largesi
number of bells, and will give the very largest percentage of first quality flowers. This grade of number of bels, and will give the very largest percentage of first quality flowers. This grade
valley is more than worth the difference in price to every grower; and we can recommend it witho hesitation, knowing that it will give perfect satisfaction.

$\$ 1.75$ per $100, \$ 15.00$ per $1,000, \$ 35.00$ per case 2,500 pips.

Pierson's Premier. This is a very fine selected Valley - a grade under Perfection-aud can a moderate price, this grade will give very satisfactory results. We have sold large quantities of and buyers have alway's been very well satisfied. It is good value at the price charged, and much
better than extra quality three-year-old German pips generally hasdled, and can be forced earlier. $\$ 1.50$ per $100, \$ 13.00$ per $1,000, \$ 30.00$ per case 2,500 pips.

Extra Quality. - This is the standard quality three-year-old German pip generally sold, and is Valley as can he handled at the price. It should never be used for very early forcing, but for
late forcing will give very good results. $\$ 1.25$ per $100, \$ 11.00$ per $1,000, \$ 25.00$ per case 2,500 pips.

\section{Cold-Storage Lily of the Valley}

Now ready for delivery.

We have a fine stock of cold-storage Lily of the Valley for immediate forcing. While new im -flowering, buycrs will find not give the requisite amount of foliage until after Jalluary ist, so that the cold-storage valley will be found preferable for very early forcing. After January Ist, new importations can be used $\$ 30.00$ per case 2,500 pips. 


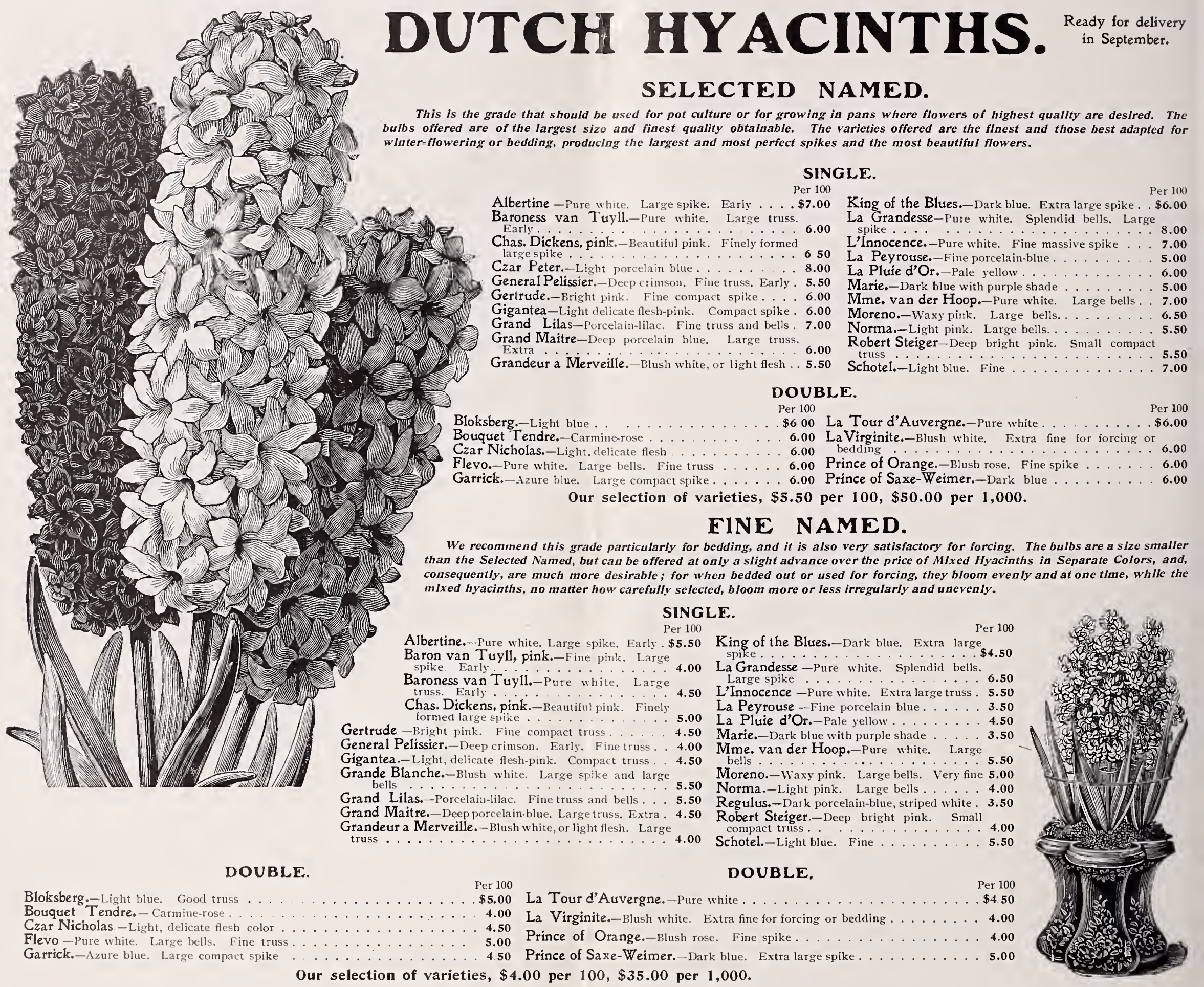




\section{DUTCH HYACINTHS.}

Ready for delivery in September.

\section{Separate Colors.}

These are largely used for bedding, and by many florists are used for forcing, but we do not recommend them for forcing, as nothing hut uamed varieties should be used for that purpose. We offer the very best quality of these and not the inferior grades which are sometimes offered for less money. SINGLE.

\begin{tabular}{|c|c|c|c|}
\hline & $\begin{array}{l}\text { Per } 100 \\
\$ \$ \mathbf{3 . 0 0}\end{array}$ & $\begin{array}{l}\text { Per } 1000 \\
\$ 27.00\end{array}$ & Rose \\
\hline Dark red & 3.00 & 27.00 & Dark red \\
\hline Blush white & 3.00 & 27.00 & Blush white \\
\hline Pure white. & 3.00 & 28.00 & Pure white. \\
\hline Light tlue & 3.00 & 27.00 & Light blue \\
\hline Dark blue & 3.00 & 27.00 & Dark blue \\
\hline Yellow & 3.00 & 28.00 & \\
\hline
\end{tabular}
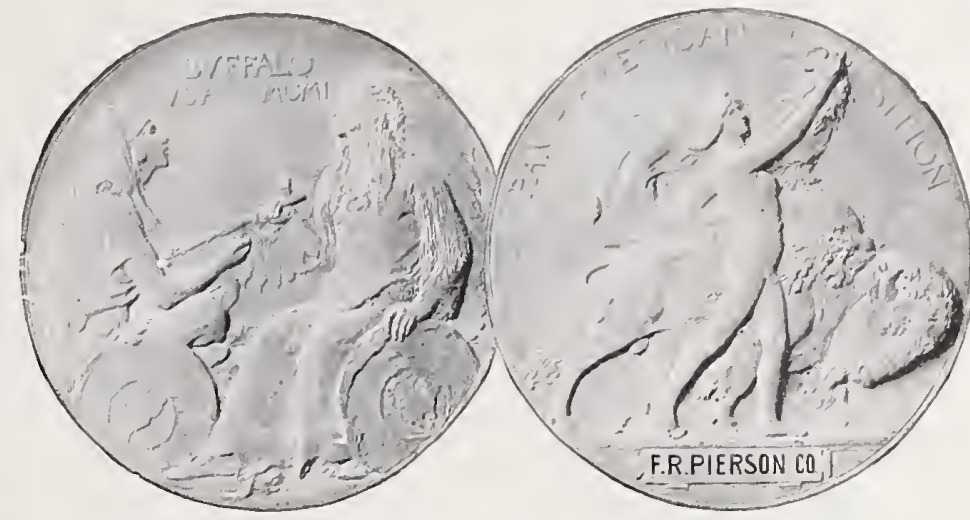

We mere aboarded GOLD MEDAL, Highest Awara,

For Our Exhibit of Bulbs at the Pan-American Exposition, Buffalo, 1901.

\section{Miniature Hyacinths, or Dutch Romans. $\begin{gathered}\text { Ready for } \\ \text { delivery in September. }\end{gathered}$}

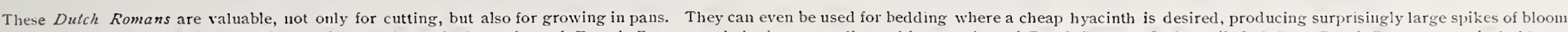

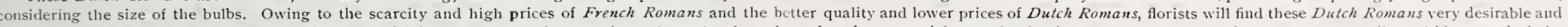

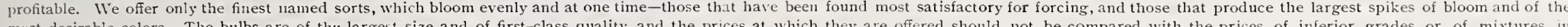
most desirable colors. The bulbs are of the largest size and of first-class quality, and the prices at which they are offered should not be compared with the prices of inferior g

separate colors usually offered, which bloom more or less irregularly, while our named sorts bloom evenly and at one time, making them very much more desirable and valuable.

\section{EXTRA SIZED BULBS, 12 TO 14 C/M IN CIRCUMFERENCE.}

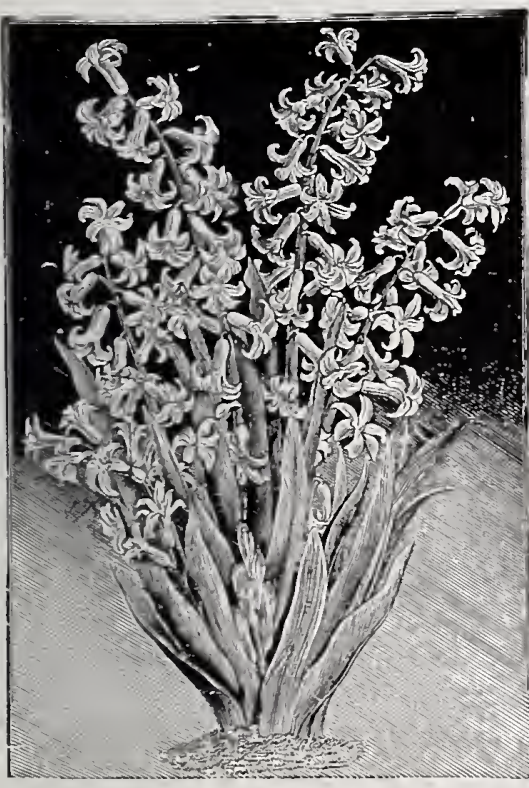

WHITE ROMAN HYACINTHS.

$\begin{array}{rrl}\text { Per } 100 & \text { Per } 1000 & \\ \$ 1.75 & \$ 16.00 & \text { Grandeur a Merveille.-Blush white } \\ 2.25 & 20.00 & \text { King of the Blues.-Dark blue . . . . } \\ 2.00 & 18.00 & \text { L'Innocence.-Pure white; extra fine. . } \\ 2.50 & 21.00 & \text { La Peyrouse.-Porcelain blue . . . . . } \\ 1.75 & 15.00 & \text { La Grandesse.-Pure white . . . . } \\ 2.00 & 18.00 & \text { Mme. Van der Hoop.-Pure white. } \\ 2.00 & 18.00 & \end{array}$

Grand Maitre.-Dark blue............ $2.00 \quad 18.00$
FOR GRAPE AND FEATHERED HYACINTHS, SEE PAGE 9.

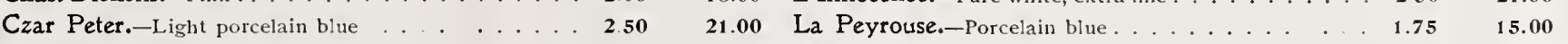

Gertrude.-Bright pink ............. $1.75 \quad 15.00$ La Grandesse.-Pure white ........... 2.50 24.00

Gigantea.-Delicate flesh-pink. . . . . . . . 2.00 18.00 Mme. Van der Hoop.-Pure white. . . . . 2.25 21.00

\section{Roman Hyacinths. Noverady}

The crop of French bulbs, especially in the larger sizes, is slort this season, owing to a long drouth which prevailed in France, but baving purchased a large quantity very early in the season, we were able to buy at much lower prices than had we purchased later, and, in consequence, are pleased to be able to offer bulbs at about as low prices as last year. The bulbs that we offer are of the very finest quality, obtained from the very best sources, carefully packed and graded, so that they cannot fail to give the very best satisfaction.

White Romans. - Extra quality bulbs, 12 to $15 \mathrm{c} / \mathrm{m}$ in circumference. $\$ 3.00$ per $100, \$ 27.00$ per 1,000

Pink Romans. - These are somewhat later than While Romans, They are very popular on account rf their heantiful color-light flesh-pink White Italians or Red-Skinned Romans. - Very desirable for late forcing, wilh much heavier flower spikes than White Romans,

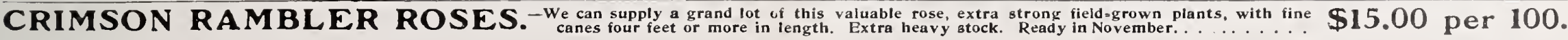




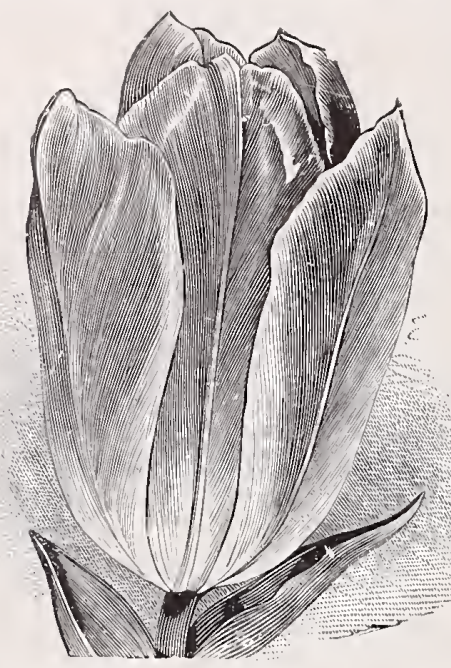

Belle Alliance (Waterloo). - - Brilliaut scarlet. An extra fine forcing variety. \$2.25 Bizard Verdict. - - vriglit red, feathered, striped, and bordered with bright yellow. A fine Cardinal's Hat. - Dark brownish red,- - somewhat like Brutus, but darker,-edge of petals 80 c. per 100, $\$ 7.00$ per 1,000 .

Chrysolora. - Pure golden yellow; extra large. Finest yellow tulip for bedding. 90c. per Cottage Maid. - Anl exquisite color, - - lovely bright pink, heavily marked with white at centre forcing variety; cannot be forced early. Extra. $\$ 1.00$ per $\mathbf{1 0 0}, \$ 8.50$ per 1,000 .

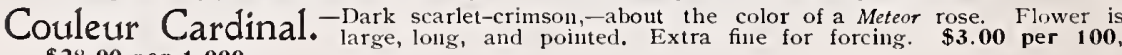
$\$ 28.00$ per 1,000

Couleur Ponceau. - Bright cherry, base of petals pure white,
bedder. 80c. per 100, $\$ 7.00$ per $\mathbf{1 , 0 0 0}$.

Crimson King. - Crimson-scarlet; very brilliant. Fine bedder, also good for late forcing. Duc van Tholl, Scarlet. - Intense dazzling scarlet. very desirahle for early forcing. Duchesse de Parma. - Orange-red, with yellow edge. very showy. A good forcer and Joost van Vondel. - Wine color, feathered with white.-an unusually striking and distinct
$\mathbf{1 0 0}$, $\mathbf{1 1 . 0 0}$ per 1,000.

Keizerskroon (Grand Duc). - - Red, heavily bordered golden yellow. Extra large fower. $\$ 1.50$ per $100, \$ 12.00$ per 1,000 .

La Reine (Queen Victoria). - White, slightly shadel pink. A favorite forcing variets: L'Immaculee. -Pure white. A fine bedding tulip, also a fine early forcing variety. Can be
forced for Cluistmas. Alnost as early as Duc van Tholl, Scarlet. 80c. per 100, $\$ 7.00$ per 1,000 .

Mon Tresor. - Pure sellow; an extra fine large flower. A little deeper yellow and a little Pottebakker Yellow. - Yellow, with light scarlet stripe. \$1.50 per 100, \$12.00 Pottebakker White, -Finest white forcing tulip; also extra fiue for bedding. Extra large Pottebakker Scarlet (Verboom). - -Dark crimsoil-carlet. Excellent for forcing or Prince of Austria. - - - Rright orange-scarlet. Strong grower and very large flower. Extra fiut Princess Marianne-A very large white tulip, slighttly tinged pink. An excellent variety

Proserpine. - Violet-rose-a lovely color. Extra large and extra fine for early forcing especially:

Rachel Ruisch. - A fine pink tulip for bedding. Bright pink, base and centre of petals white; recommend this
$\$ 9.00$ per 1,000 .

\author{
Ready for
}

FINEST VARIETIES FOR FORCING AND BEDDING.

Gold Medal, Highest Award, Pan-American Exposition, May, 1901.

On this page is a photograph showing part of our large exhibit of tulips at the Pan-American Exposition. We planted there about fifty thousand bulb The varieties used in our exhibit were Artus, Joost van Vondel, Rosamundi Huykman, Bizard Verdict, Cardinal'

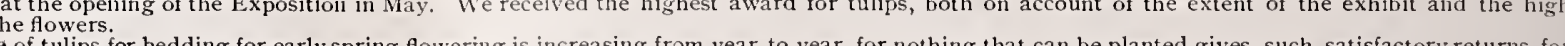

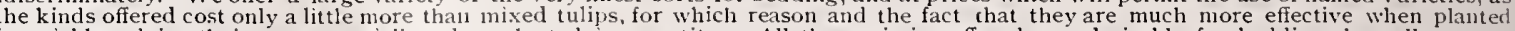

\section{SINGLE EARLY TULIPS.}

Rosamundi Huykman. - Rose-pink, with broad white stripe in centre of each petal. Larce later than that variets. 90c. per $100, \$ 7.50$ per 1,000 .

Rose Falcon. - Delicate pink. valuable for forcing. \$3.50 per 100, \$30.00 per Rose Grisdelin. - Cost pink tulip for early forcing. Lovely delicate pink, - a little lighter than Rose Luisante. ${ }^{-S u p e r b}$ rose. Very large and extra fine. $\$ 3.00$ per $100, \$ 26.00$ per

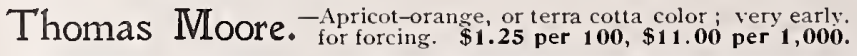

Vermilion Brilliant. - Finest of all scarlets for forcing. and the most brilliant of all scarlets. per 1,000 .

Wapen van Leiden. - Creamy white, with broad deep carmine stripe at the top of each $\$ 1.00$ per $100, \$ 8.50$ per 1,000 .

Yellow Prince. - The standard yellow forcing tulip; also fine for bedding. When beddert

Finest Mixed. - The mixcd tulips offered by us are much superior to ordinary mixtures, being differcnt colors. We can recommend this nisture to any one wanting mised tulips. 80c. per 100 ,
$\$ 7.00$ per 1,000

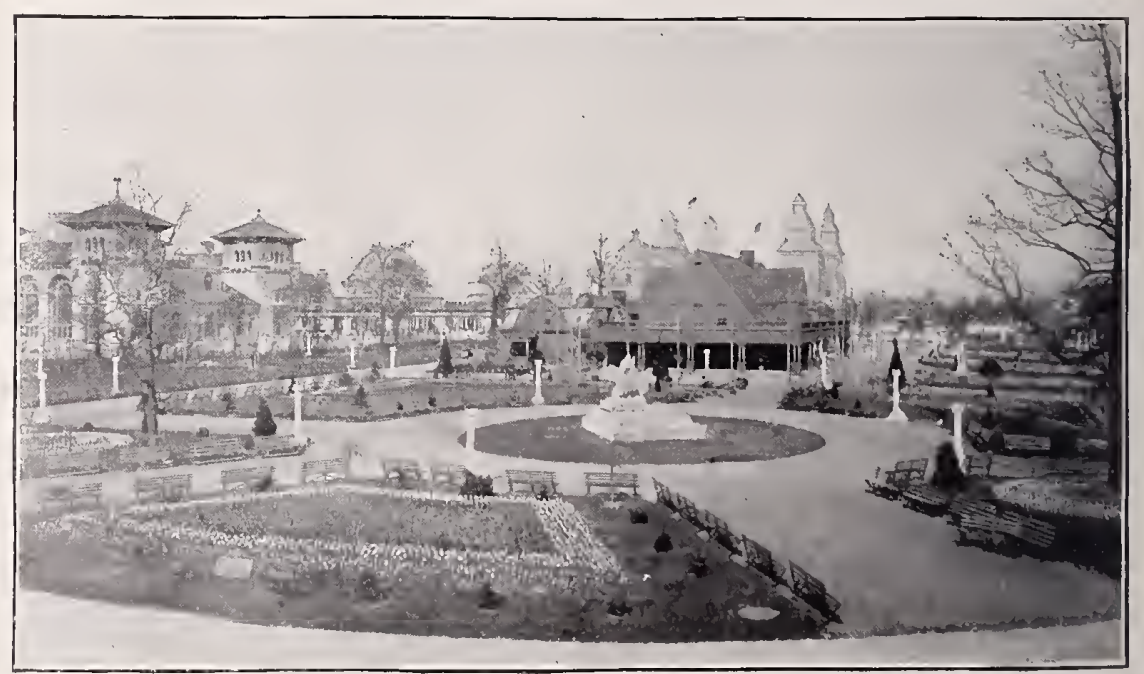

Bird'seve View of our Exhilit of Tulips at the Pan-Americun Exposition 


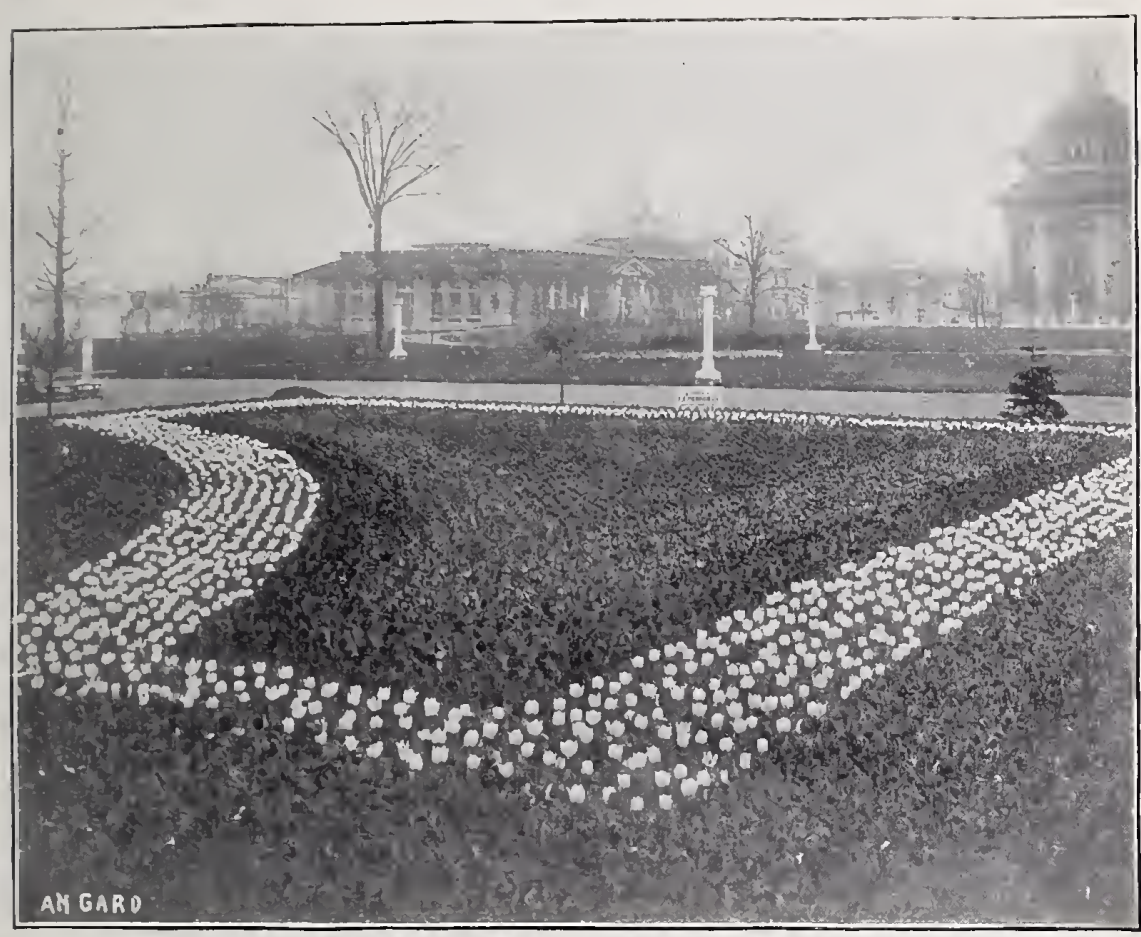

View of one of our beds of Tulijs at Pan-American Exposition, containng $\mathbf{1}_{3}, 000$ Bulbs

SINGLE LATE TULIPS.

These late tulips are exceedingly fine for planting in borders of shrubbery, and, if possible, should be planted where they can be left from year to year. They grow taller than the early varieties, and the flowers are larger and showier also than other tulips. Their season of blooming is very long. They desirable for cut flowers, but on account oi being la beond are

Bizards, - Very showy flowers, beautifully blotched, striped, and feathered with crimson, pint, Byblooms. Flowers beautifully hlotched, striped, and feathered with crimson, pink, scarlet, rose,
1,000 .

Bouton d'Or. - Pure yellow. Remains in bloom three weeks, flowers increasing in size as the per 1,000 .

Darwins. - These are what are termed selfs, or solid colors, and are mostly dark shades, no whites

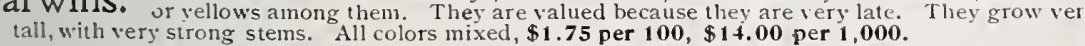
Gesneriana Spathulata. - This is the true Gesneriana and the finest of all late tulips $\$ 1.75$ per $100, \$ 1400$ per 1,000 .

Golden Crown. - Sometimes called The Vellow Gesneriana. Vellow, with scarlet edge. Ver

Picotee (Maiden's Blush). A magnificent tulip. White, heautifully margined and beautiful. $\$ 2.00$ per $100, \$ 17.00$ per 1,000 .

Parrots. - Very singular and beatiful, both in shape and markings. Yery highly colored. Markings

Admiral of Constantinople.-Orange-scarlet.

Lutea Major.-Golden yellow.

Perfecta.- - Vellow, scarlet stripe.

Markgraff van Baden.-Inside of flower orange-ıellow; outside striped scarlet. $\$ 1.25$ per $100, \$ 10.00$ per 1,000 .

Parrots. - All colors mixed, $\$ 1.00$ per $100, \$ 7.50$ per 1,000 .

\section{DOUBLE TULIPS.}

Count of Leicester. -Orangc-yellow. Earlier than Yellow Rose, $\$ 1.25$ per $100, \$ 10.00$ Couronne d'Or. - Y $\mathrm{d}^{\prime}$ llow, shaded orange. Extra fine for forcing. \$3.25 per 100, \$30.00 Duke of Y ork.-Carmine, elged white. Good tor forcing. \$1.25 per 100, \$9.00 per 1,000. Gloria Solis. - Crimson, with yellow margin. Fine bedder; one of the showiest tulips for this in color; cannot be lorced so early. \$1.50 per $100, \$ 11.50$ per 1,000 .

Imperator Rubrorum. - $\$ 2.50$ per $\mathbf{1 0 0 , \$ 2 2 . 0 0}$ per $\mathbf{1 . 0 0 0}$. La Candeur. - Pure white. Fine for bedding, and also for Easter forcing. \$1.25 per 100, Lady Grandison. - Bright scarlet. Very early. Fine for bedling. \$1.25 per 100, \$10.00 Le Blason.-Delicate rose, shaded and striped white. $\$ 1.50$ per $100, \$ 12.00$ per 1,000 . Mariage de ma Fille. - White, striped cherry red. Extra fine late variety. The lisgest Murillo, -A magnificent flower, hlush white, shaded rose. Large fine flower. Fxtra fur forcing. Paeony Red. - Fine scarlet for bedding; late; blooms with Vellow Rose. $\$ 1.25$ per $\mathbf{1 0 0 .}$ Rex Rubrorum. - Extra fine scarlet for bedding. Large, full, double fower. Produces a $100, \$ 13.00$ per 1,000 . Rose Blanche. ${ }^{- \text {Pure whin }}$.

Salvator Rosa. - Deep rose, flamed white. Highly recommended for very early forcing. Tournesol Red and Yellow. - Scarlet, bordered yellow. Extra fine for forciny. ExTournesol Yellow. -Pure yellow. Extra fine for early forcing. $\$ 3.00$ per 100 , $\$ 25.00$ Yellow Rose.-Bright yellow. Late. 90c. per 100, $\$ 7.50$ per 1,000 .

Finest Mixed.--All colors. $\$ 1.00$ per $100, \$ 8.00$ per 1,000 .

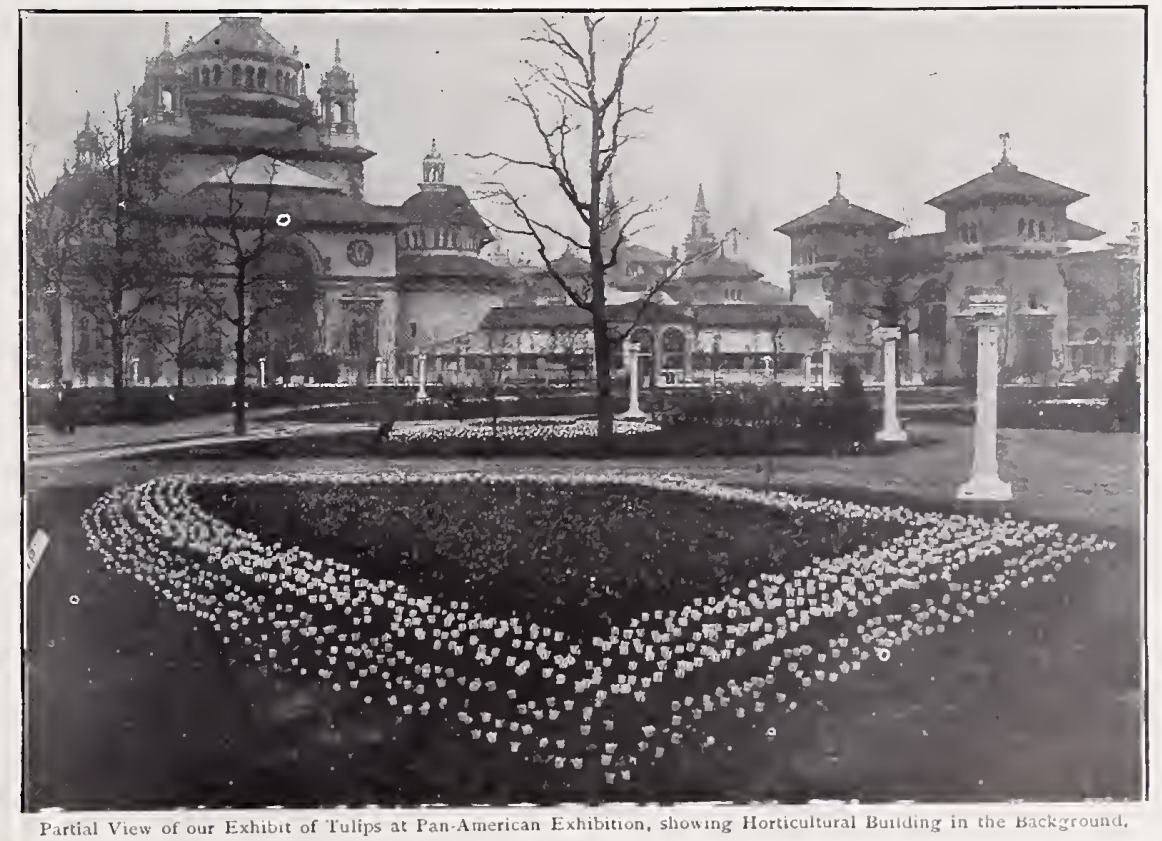

RECEIVED HIGHEST AWARD PAN-AMERICAN EXPOSITION FOR OUR EXHIBIT OF TULIPS, MAY, 1901. 


\section{NARCISSUS. Rathinatianer}

\section{LARGE SINGLE TRUMPETS.}

Empress. - A magnificent variety, white perianth with rich yellow trumpet. Flowers large and of $100, \$ 20.00$ per 1,000 .

Emperor. Deep yellow trumpet, sulphur perianth. Immense. The finest of this section. $\$ 2.00$ Golden Spur. - A magnificent single trumpet narcissus with enormous flowers of deep golden Grandee (Iaximus). - Yellow trumpet, white perianth, broad petals. Late flowering; Horsfieldi. - Large golden yellow trumpet and pure white perianth. A grand variety for early . Henry Irving. - Magnificent flower with large golden yellow trumpet beautifully $\mathrm{fr}$ broad and wide; overlapping. $\$ 2.00$ per $\mathbf{1 0 0}, \mathbf{\$ 1 6 . 0 0}$ per $\mathbf{1 , 0 0 0}$.

Princeps (The large Irish Single Yellowe Trumpet Daffodil).-Magnificent large blooins; light variety for florists on account of its earliness and the low price at which the buibs can be offered. $90 c$. per 100, $\$ 7.50$ per 1,000 . Large selected bulbs, $\$ 1.25$ per $100, \$ 10.00$ per 1,000 .

Single Von Sion. - We recommend this strongly in place of Trumpet Major especiallv for yellow, larger flower, and a much better bloomer. The best pure yellow moderate-priced single
trumpet narcissus. $\$ \mathbf{1 . 2 5}$ per $\mathbf{1 0 0}, \mathbf{\$ 1 . 0 0}$ per $\mathbf{1 , 0 0 0}$.

Trumpet Mlajor. - F a favorite sort. $\$ 1.00$ per $100, \$ 9.00$ per 1,000 .

Trumpet Major (French-grown) $\begin{gathered}\text { for Christmas=flowering.-Desirable, as it can } \\ \text { be had }{ }_{i 11} \text { bloom by Christmas, before other }\end{gathered}$ varieties are in the market. For this purpose it should be started very early, during August or
early in September. \$2.00 per $\mathbf{1 0 0} \$ \mathbf{\$ 1 5 . 0 0}$ per 1,000.

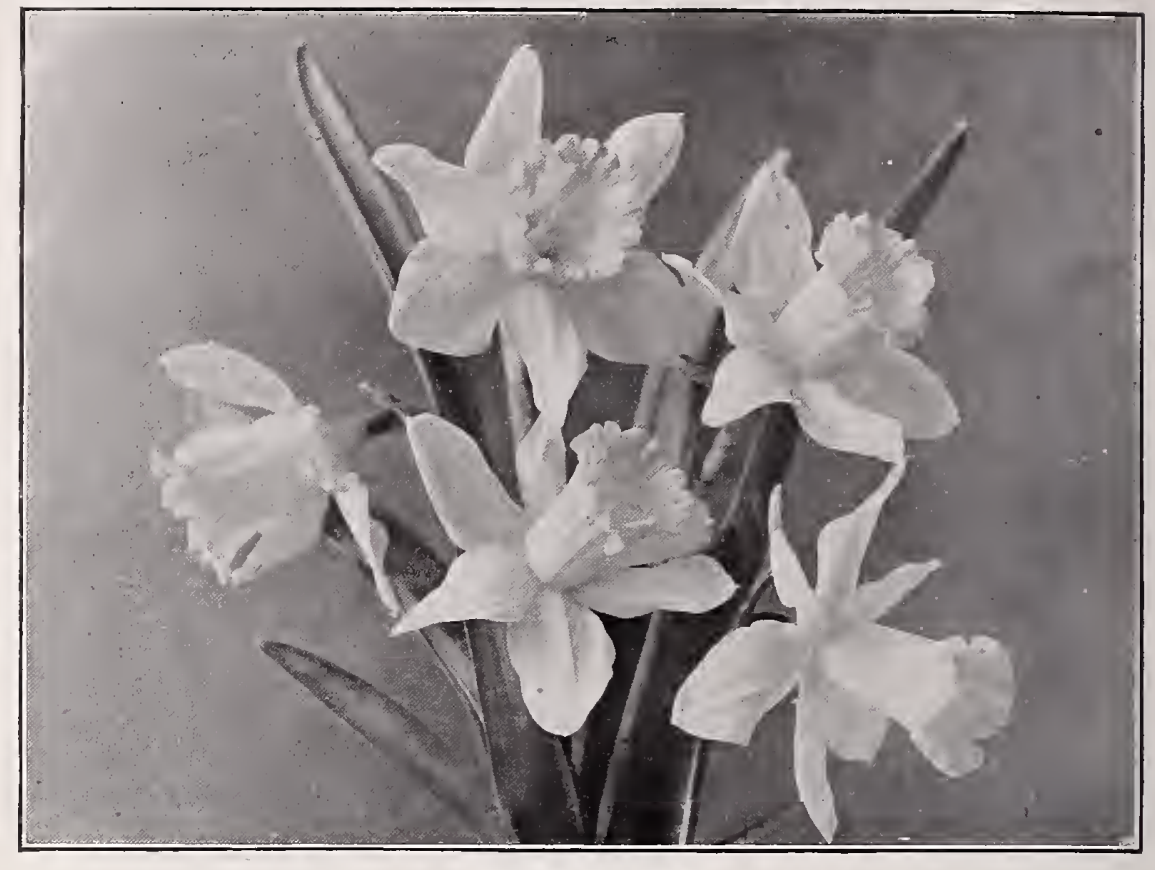

MISCELLANEOUS SORTS.

DOUBLE FLOWERED.

Double Von Sion, or Double Yellow Daffodil. This is one of the most useful and profitable of winter-flowering bulbs,
and is forced in large quantities. There is nothing in which quality and is forced in large quantities. There is nothing in which quality
is so important as in Von Sions-color and form of flower, size of is so important as in Those who have been troubled with "Green
our stock. Growers will find it will pay to buy the best Von Sions obtainable.
Selected mammoth double-nosed, or top-root, bulbs, $\$ 2.25$ per $100, \$ 20.00$ per 1,000 .
Extra sized bulbs, $\$ 1.50$ per $100, \$ 12.00$ per 1,000 .

Alba. Plena Odorata. - Double; pure white gardenia-like per 100, $\$ 6.00$ per 1,000 .

Incomparable fl. pl. (Butter and Eggs).-Full douhle golden $\$ 1.00$ per $100, \$ 7.00$ per 1,000 .

Orange Phoenix. (Eggs and Bacon).-Double; white flowers per 1,000 .

Silver (Sulphur) Phoenix. (Codlinsand Cream) - Sulphur$100, \$ 20.00$ per 1,000

\section{PAPER WHITE GRANDI- FLORA.}

Now ready for delivery.

Much larger and better than the ordinary variety, blooming in larger clusters and coming into flower earlier. Crop is short this season, and already covered their requirements to lose no time doing so. The bulbs that we offer are of the very finest quality obtainable.
Extra quality bulhs, $13 \mathrm{c} / \mathrm{m}$ and up in circumference, 1.500 bulbs to the case, $\$ 1.25$ per $100, \$ 10.00$ per 1,000 .

case, $\$ 1.50$ per $100, \$ 12.00$ per 1,000 .

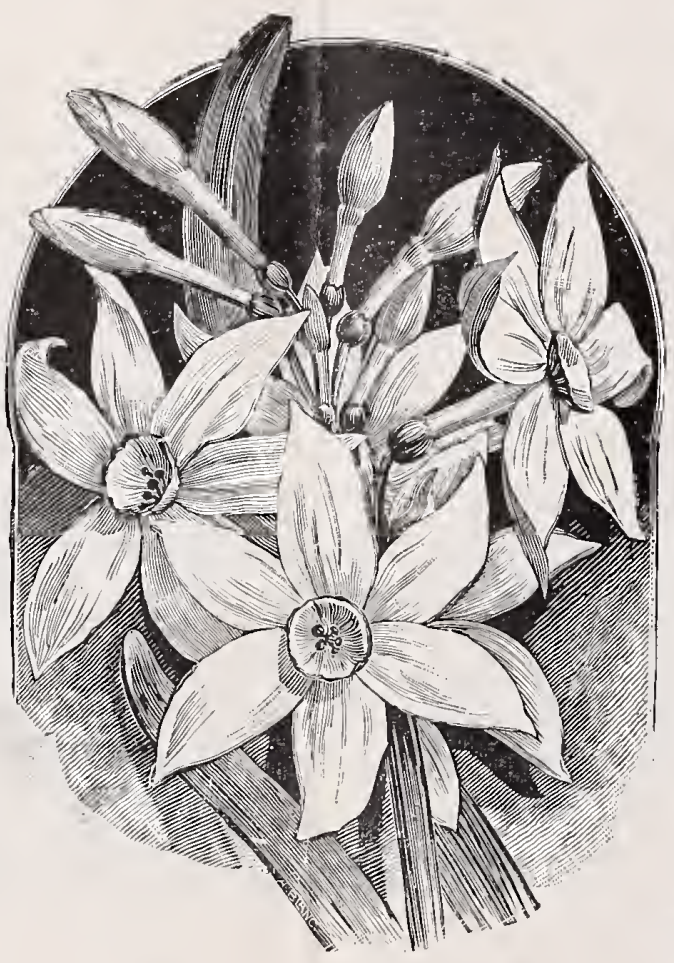

Barri Conspicuus, - Beautiful canary-yellow, with deep Flowers three to three and a half inches in diameter, borne on long $\$ 7.50$ per 1,000 .

Incomparable Stella. -White star-shaped fower, with yellow most easily forced of all the narcissus. $75 \mathrm{c}$. per $100, \$ 5.00 \mathrm{per}$ 1,000. (Pheasant's Eye).-Pure white with red cup. Very useful out-of-doots, where it is perfectly hardy, and will blooin year after

Poeticus Burbidgei.-A very early-flowering variety of

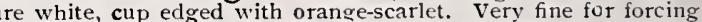
and outside planting. $75 \mathrm{c}$. per $100, \$ 5.50$ per 1,000

Poeticus Ornatus - The Improved Poeticus. Pute white with Scarlet ring; inuch finer in form and much earlier than Poeticus. A magnificent cut flower. This is becoming more and 1,000 .

\section{JONQUILS.}

Giant Campernelle Jonquil Rugulosus. ${ }_{\text {Iarcer }}^{\text {Much }}$ and finer than the old favorite Campernelle Jonqunl, a much freer bloomer, and much more desirable, especially for torcing. Beautiful single yellow star-shaped hower, delight ully fropart. hardy, and invaluable tor outdoor planting. 75c. per 100, \$6.50 per 1,000 .

Double Jonquil. - Bears clusters of small very double deep fumed. $A$ favorite for forcing and outside planting. $\$ 1.00$ per CHINESE SACRED LILY.

\section{Ready in October.}

(Narcissus orientalis) - A fororite hulb for retailing, as it makes a We offer the finest quality bulbs, grown in China, insuring a luxuriant growth and a remarkable profusion of flowers. Single basket (30 bulbs) thousand lots at \$40.00 per 1,000 .
Poeticus (Pheasant's Eye).-Pure white with red cup. for cutting in spring, and it can be planted in borders fine house plant, and is one of the best selling bulbs for this purpose. 


\section{ALLIUM NEAPOLITANUM.}

60 c. per $100, \$ 4.50$ per 1,000 .

AMARYLLIS JOHNSONI. The most popular and finest of all the amaryllis. L

\section{ANEMONES}

The Bride.-Single Pure white, 75c, per $100, \$ 5.00$ per 1,000 Single - All colors mixed. $75 \mathrm{c}$. per $100, \$ 5.00$ per 1,000 Double. - All colors mixed. $\$ 1.00$ per $100, \$ 8.00$ per 1,000

\section{CHIONODOXA LUCILIAE}

Deep blue, with white centre. $75 \mathrm{c}$. per $100, \$ 6.00$ per 1,000 .

\section{DIELYTRA SPECTABILIS}

\author{
Bleeding Hear
}

Ready for delivery in November.

Strong Clumps. $-\$ 8.00$ per 100

GRAPE AND FEATHERED HYACINTHS.

Blue Grape.-50c. per $100, \$ 4.00$ per 1,000

White Grape. $-75 \mathrm{c}$, per $100, \$ 6.00$ per 1,000 Feathered. $-\$ 1.00$ per $100, \$ 8.00$ per 1,000 .

\section{HYACINTHUS CANDICANS}

(Cape Hyacinth).

in height, bearing

A summer-flowering bulb, three to five feet
pure white bell-shaped flowers. $\$ 2.50$ per $\mathbf{1 0 0}$.

\section{SPANISH IRIS.}

Extra fine mixed varieties. 50c. per $100, \$ 3.00$ per 1,000 .

IXIAS.

Finest Mixed.-Yery showy and brilliant; well adapted for cut 50c. per $100, \$ 3.00$ per 1,000 .

\section{OXALIS.}

Bermuda Buttercup.-This has met with a very large sale, as it is

an ideal house plant. Blooms all winter long. Flowers are of

good size; hright golden-yellow. We offer extra sized Bermuda-
grown stock. 75c. per $\mathbf{1 0 0} \$ \mathbf{6} .00$ per $\mathbf{1 , 0 0 0}$ Alba.-White. 75c. per 100.

Boweii.-Pink; large. 75c. per 100.

Versicolor,-Red and white. 75c. per 100

\section{DOUBLE RANUNCULUS.}

French.-All colors mixed. 50c. per $100, \$ 3.00$ per 1,000 Persian.-All colors mixed. 50c. per $100, \$ 4.00$ per 1,000

Turban.-All colors mixed. 75c. per $100, \$ 5.00$ per $\mathbf{1 , 0 0 0}$.

\section{SCILLA.}

Siberica. - Bright blue; early. 75c. per $100, \$ 6.00$ per 1,000 Campanulata Cerulea.-Blue; tall.
$75 \mathrm{c}$. per 100, $\$ 6.00$ per $1,000$.

\section{SNOWDROPS (Galonthus).}

Single. $-75 \mathrm{c}$. per $100, \$ 6.00$ per 1,000 .

Double $-\$ 1.25$ per $100, \$ 10.00$ per 1,000 .

Giant (Galanthus Elwesii). $-75 \mathrm{c}$. per $100, \$ 6.00$ per 1,000 .

\section{SPARAXIS.}

50c. per $100, \$ 3.00$ per 1,000

\section{Crocus.}

MAMMOTH BULBS.

These are extra large selected bulbs, averaging $1 \frac{1}{1 /}$ in and up in diameter. Varieties offered are also of the very finest quality. They are very desirable for forcing, and these large bulbs are much finer

$\begin{array}{ll}\text { Mont Blanc.-Snowy white. } & \text { La Majestueuse.-Violet, striped white. } \\ \text { David Rizzio.-Dark blue. } & \text { Purpurea Grandiflora.-Dark purple; }\end{array}$

$\begin{array}{ll}\text { Mont Blanc.-Snowy white. } & \text { La Majestueuse.-Violet, striped white. } \\ \text { David Rizzio.-Dark blue. } & \text { Purpurea Grandiflora.-Dark purple; }\end{array}$

Purpurea Grandiflora.-Dark purple; ver

p golden yellow: 54.00 per 1,000
50c. per $100, \$ 4.00$.

\section{FINE NAMED VARIETIES.}

These are first sized bulbs and a first-class article where moderate priced crocus

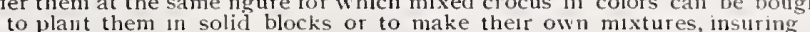
enabling buyers to plant the
equal assortment of colors.

Prince Albert.-Dark purple. $\quad$ Large Yellow,-Pure golden yellow. Sir Walter Scott.-Violet, striped white. Mont Blanc.-Snowy white.

Baron von Brunow. Purplish blwe.

$40 \mathrm{c}$. per $100, \$ 3.00$ per 1,000 .

SEPARATE COLORS.-Blue, White, Yellow, Striped. 30c. per 100, \$2.25 ALL COLORS MIXED.-25c. per 100, $\$ 2.00$ per 1,000 .

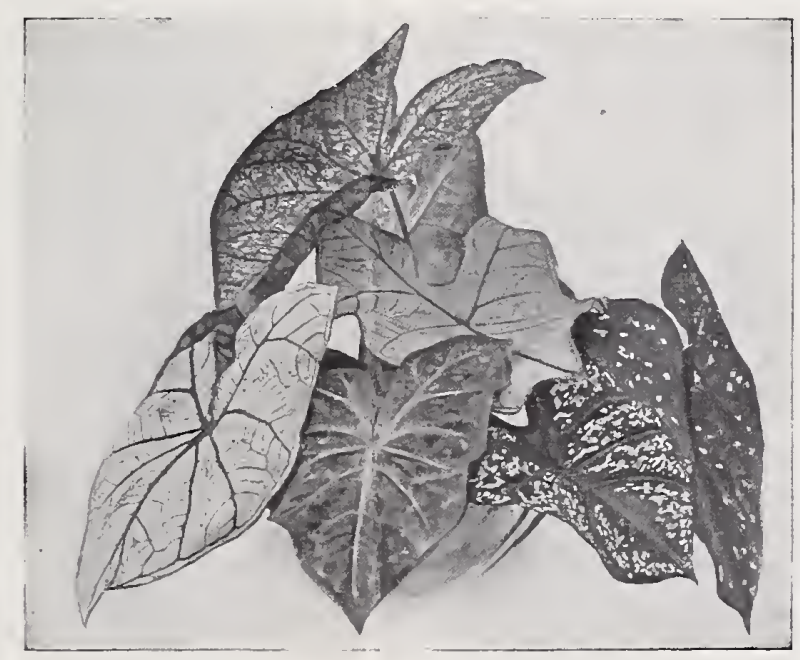

FANCY-LEAVED CALADIUMS.

\section{Ready in December.}

We can supply a fine assortment of the very choicest named varieties, very distinct and very desirable--strong dornant bullos of
large size. Thes bulbs are gyown out-of-doors, and will be found superior to greenhouse-grown plants. Tubers are

\section{CALADIUM ESCULENTUM.}

Bulbs 6 to 9 in. in cir. $\$ 3.00$ per $100, \$ 25.00$ per 1,000 .

\section{TUBEROSE PEARL.}

\section{Ready in December.}

Our bulbs are grown in the South, where the climate and soil are peculiarly adapted for their perfect development, and the stock we

Extra quality hulbs, $\$ 1.00$ per $100, \$ 7.50$ per 1,000 .

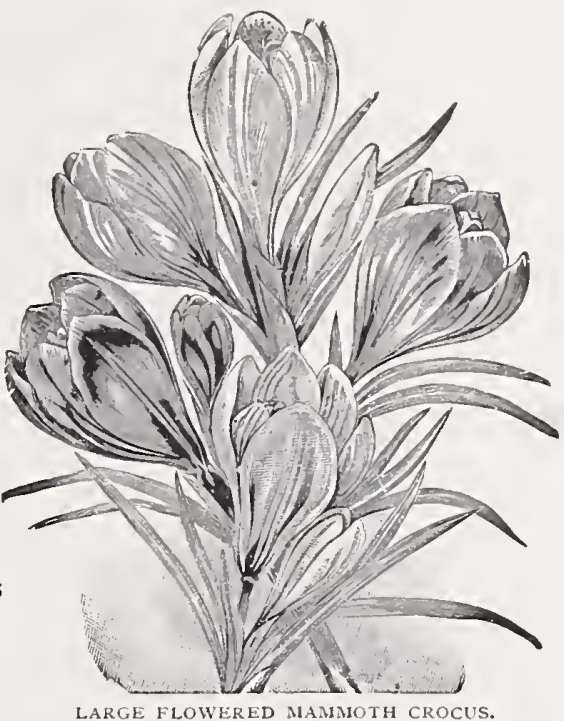

Tuberous-Rooted Begonias.

Having made arrangements with one of the largest and fines growers ol Tuberous Begonias inl Europe to supply us with hi low prices. Bulbs are first-class, running $\mathrm{I}^{1 / 4} / \mathrm{inch}$ in diameter and up. The quality of the flower, notwithstanding the low price, is unusually fille. There is no finer stock to be had in Europe. port their own stock direct. Double. $\$ 5.00$ per $100, \$ 40.00$ per 1,000

\section{GLOXINIAS}

We handle these very largely, and our strain of Hybrida

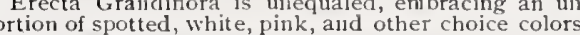
Finest Mixed. $-\$ 4.00$ per $\mathbf{1 0 0}, \$ 30.00$ per 1,000 . parate Colors.- $\$$ herte; red 100

\section{DAHLIAS.}

We have a superb collection of dahlias, finest named sorts,
mprising cactus and decorative, large-flowering o comprising cactus and decorative, large-flowering o varieties. When selection of varieties is left to us, customers can rely on receiving a fine assortment. In ordering, state which comprising all the different classes. Finest named sorts, $\$ 8.00$

\section{GLADIOLI.}

White and Light. $-\$ 1.75$ per $100, \$ 15.00$ per 1,000 Scarlet and Red. $-\$ 1.25$ per $100, \$ 9.00$ per 1,000 Yellow and Orange. $-\$ 3.00$ per 100 .

Pink and Rose $-\$ 1.50$ per $100, \$ 12.00$ per 1,000 Striped and Variegated. $-\$ 2.50$ per $100, \$ 20.00$ per 1,000 Groff's Hybrid Seedlings.-All colors mixed ; the most popul strain in America. $\$ 2.00$ per $100, \$ 18.00$ per 1,000 . per 1,000

Lemoine's Hybrids. -Finest mixed. $\$ 1.50$ per $100, \$ 12.00$ Extra Superfine Mixed.-\$1.25 per 100. $\$ 9.00$ per 1,000

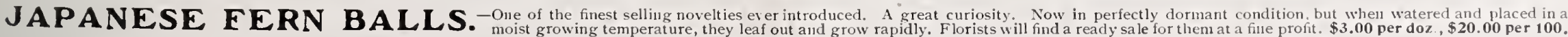




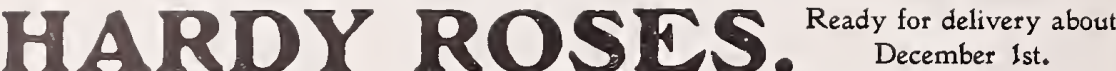

\section{Extra Strong Two-Year-Old Field-Grown Plants.}

Frau Karl Druschki. - This is a queen a mong white roses. Flowers are of the largest size, pure full and of the most beautiful form, $A$, continuous and tree-blooming variets. Undoubtedly the finest Capt. Hayward. - Very large. Bright carmine-crimson. Very choice. \$2.50 per dozen.

Mrs. R. G. Sharman-Crawford. - Deep rosy pink, outer petals shaded pale flesh. Very large in autumin. Awarded gold medal National Rose Society, England. $\$ 2.50$ per dozen
Soleil d'Or. prize at the Paris Exposition and numerous gold medals throughout Europe. \$2 50 per dozen. Margaret Dickson. - White, with slight tinge of satuly rose; large and ot excellent folm. Ulrich Brunner, - An eleegant flower, finer every way than Gen. Jacqueminot; bright cherry Baroness de Rothschild. - Light pink, sometimes shaded with rose; very large; cupped form Paul Neyron. - A grand rose. The flowers are immense, dark rose color, double and handsomely Gen. Jacqueminot.-Bright crimson-scarlet, exceedingly rich and velvety. The buds and parll Magna Charta.-Immense flowers. One of the largest roses grown. Rich dark pink. Superb. Mrs. John Laing. -One of the finest varieties, bloming almost constantly. The buds are long double, borne on lony, straight stems. A lovely shade of delicate pink, exquisitely fragrant. centre. One of the sweetest and most beautiful roses.

Marshall P. Wilder.-Crimson-vermilion; exquisitely shaded and richly perfumed.

Gloire de Paris (Anna de Deisbach).A most lovely shade-clear, bright rose; very large and Baron de Bonstetten. - Velvety maroon, shaded with deep crimson; very dark and rich in Prince Camille de Rohan-One of the richest dark crimson roses. It resembles Gen.

Capt. Christy.-Delicate flesh with rosy centre. Very free bloomer. Extra.

Fisher Holmes. - Flowers crimson-scarlet; large, full, and of perfect form. Free blooning and jules Margottin.-Carmine-rose. Large and full. Very free bloomer.

Perle des Blanches, ${ }^{-A}$ rery free-blooming white variety. Flowers of medium size, very full and Alfred Colomb.-Brilliant carmine-crimson, of fine globular form. Very fragrant.

Persian Yellow. - Bright yellow-a color very scarce among hardy roses. Foliage is sweetly Blanche Moreat1.-By far the best white moss rose. Long, pointed buds, beautifully mossed. Chapeau de Napoleon, or Crested Moss. - Beautiful clear pink. Buds crested, ancl Rugosa Rubra.-Deep rose. $\$ 2.00$ per dozen, $\$ 12.00$ per 100 except where noted.

\section{MONTHLY AND HYBRID TEA.}

Mildred Grant. - A magnificent hybrid tea with exceedingly long, pointed, conical buds. White. American Beauty.-Deep rose, Very large and full. Exquisitely fragrant. Constant bloomer. La France. - Silvery rose, with a satiny sheen. No variety can surpass it in delicate coloring. Gruss an Teplitz (Crimson Hermosa). - Flowers richest scarlet, shading to velvety crimson. The Maman Cochet. - Magnificent pillk, almost identical with Britesmaid in form and color. Buds White Maman Cochet. - - Buds long pointed, pure snowy white. Identical in every respect with Belle Siebrecht.-Dark carmine-pink, very rich. Flowers large and beautifully formed. Long, Hermosa. - Deep pink. An old-time favorite. One of the showiest and most satisfactory roses for Mme. Caroline Testout. - An exquisite pink rose; buds of loveliest shape and color. Blooms Kaiserin Augusta Victoria. - $\begin{gathered}\text { A grand white constant. blooming summer rosc, with buds of } \\ \text { the larest size, pure white, and of ideal form. }\end{gathered}$ Gloire de Dijon.-A combination of rose, salmon, and yellow. Very large and full. Universally Lady Mary Fitzwilliam.-Delicate rose $\$ 3.00$ per dozen, $\$ 18.00$ per 100 , except where noted.

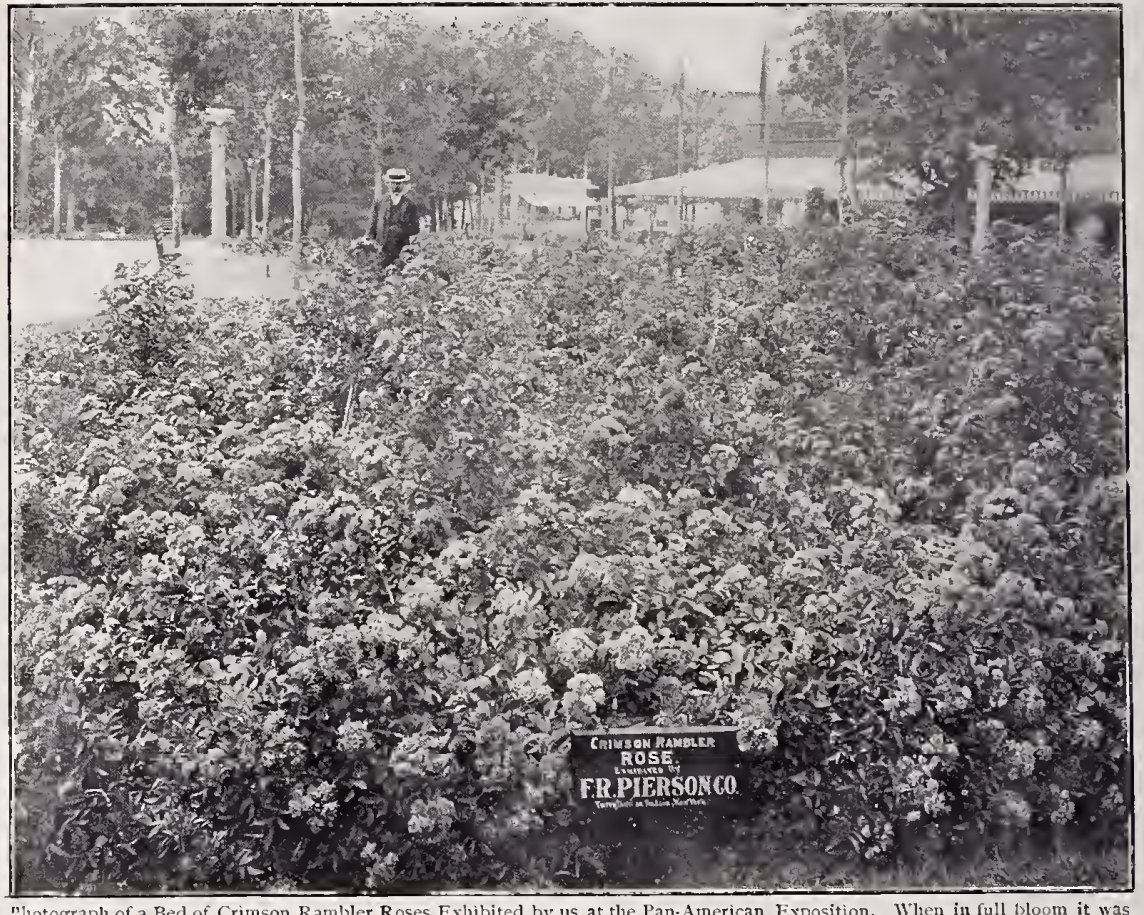

inson Ramller Roses Exilubited by us at the Pan-American Exposition,
estimated there were not less than 300,000 fowers open at one trune.

New Dwarf Perpetual-Flowering Crimson Rambler MME. NORBERT LEVAVASSEUR.

A dice forozing ever-bloming Crimson Rambler, growing from one and a half feet to two feel high, blooming when very small, bearing c'usters of flowers as large as Crimson Rambler, identical in form and color. As a bedding rose it is unequaled, especially so, as it blooms constantly throughout the summer. The grandest introduction in roses since Crmason Rambler, and will prove evell more valuab.
than that phenomenal variety. A grand accuisition. A first-class addition to plants for Easter forcing.

Extra strong field=grown plants, $\$ 1.00$ each, $\$ 9.00$ per dozen, $\$ 50.00$ per 100 .

\section{CRIMSON RAMBLER.}

Nothing equals this variety as an all-round hardy garden rose, on account of its brilliant color profusion of bloom, and length of time the flowers last. It may be used as a climber, or may be grown in large bush form; or, by tying down, can he used for bedding, and when grown in this way it is the $\$ 15.00$ per 100 .

New Pink Rambler DOROTHY PERKINS.

A pink climbing rose which will prove as popular as Crimson Rambler. It has exactly the sam habit, the foliage is identical, and it is alike remarkable for the great freedom with which the flower are produced. The only difference is in the color, Dorothy Perkins bsing a beautiful shell-pink. Valuable not only as a climbing rose, but a grand rose for bedding and also for forcing. $\$ 3.00$ per dozen, $\$ 20.00$ per 100 .

New Single Rambler Rose LEUCHTSTERN.

This new single iose is exceelingly showy aud autactive It is a woleruily free bloomer, with large single flowers, bright rose, with a large white eye. Habit of growth and foliage are similar to large single flowers, hright rose, with a large white
Crimson Rambler. 35c. each, $\$ 3.50$ per dozen.

STANDARD, OR TREE, ROSES.

Crimson Rambler. - Nothing is so well adapted for growing in standard form. Hybrid Perpetuals, Assorted Named. - Finest assortment. \$5.00 per dozen. \$35 00

Rhododendron Maximum and Kalmia Latifolia. 


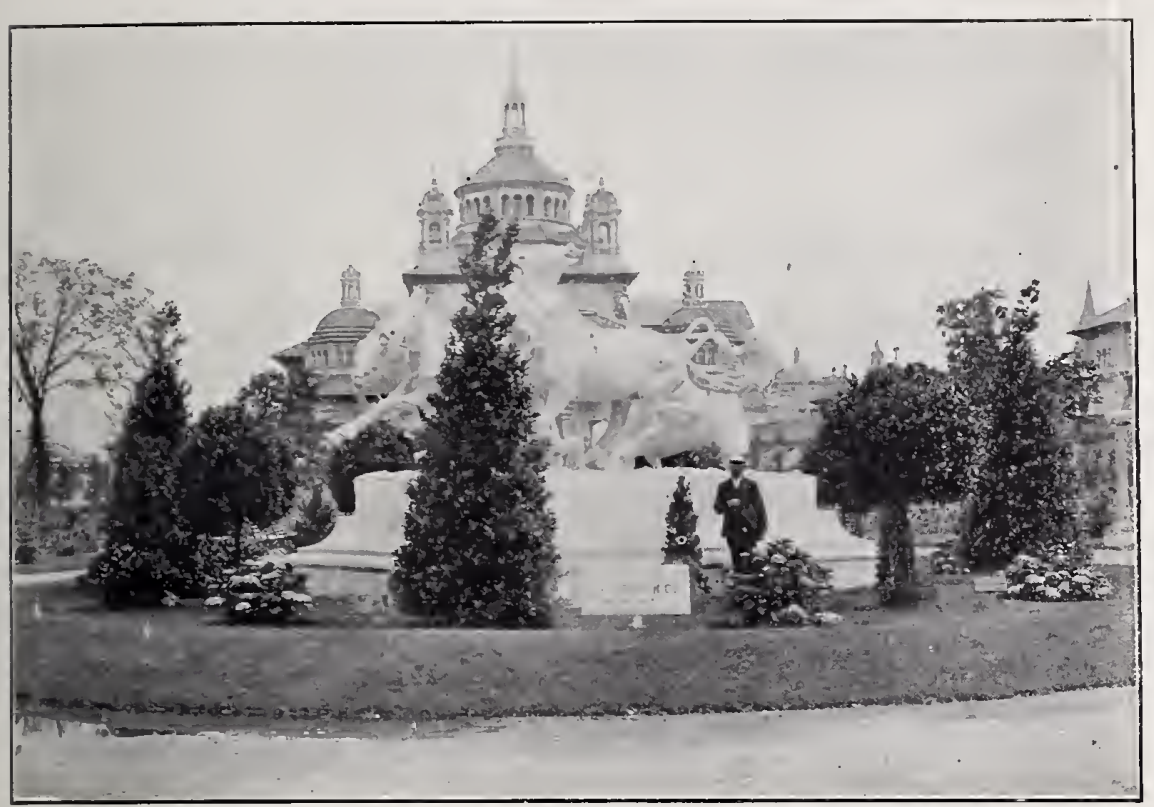

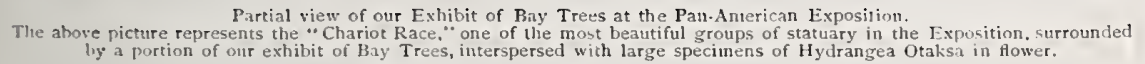

\section{Azaleas. $\begin{gathered}\text { Ready for } \\ \text { delivery in October. }\end{gathered}$}

Next to the Easter lily these are the most important plants for Faster decoration. We shall have
to ofier from October until Easter a fine assortment of plants, with five crowns. well shaped and well hudded. Orders will be booked at these special. low import prices for delivery in October and November. prices advance later in the season, and while the plants can be shipned by freight, as early int llie season
pring plants travel as salely by freight as by express, and at a great saving in cost of transportation. These

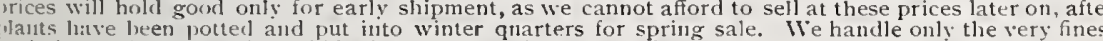
Apollo.

Apollo.-Orange-scarlet.

Bernhard Andrea Alba.-Double. Pure

Deutsche Perle. - Douhle. Pure white.

Dr. de Moore.-Douhle. Deep rose, shaded

Empress of India. - Double. Variegated

Madame Van der Cruyssen.-Double.

Niobe. -Double. Pure white, with finel

Paul Weber - very double. Similar to Ver-

Pauline Mardner. - Ver early. Bright

Professor Wolters. - Single. Magnificent

very deep carmine blotch and sladings, with

Simon Mardner. - Very donbls. B riglit

pleasing slade and rery desirable.

Vervaeneana. - Double. White, sa $1 \mathrm{mon}$ markings in centre of flower.

SPECIAL LOW IMPORT PRICES. FALL DELIVERY.

Strong plants, 10 to 12 in. in. diameter, $\$ 4.80$ per dozen, $\$ 35.00$ per 100.

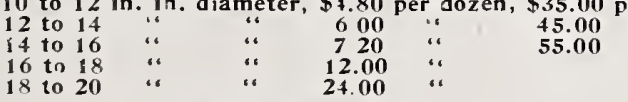

Azalea Mollis.

This is largely nsed in Europe. and is being more largely used in this country for forcing. The colors are entirely differellt
Fine bushy plants, well budded, 12 to 15 in. high, $\$ 4.50$ per doz, $\$ 30.00$ per 100 .

\section{Pot-Grown Lilacs. Reatin in}

We offer the best varieties for forcing for winter flowers, - Marie Legraye, Mme. Lemoine, and
Charles X. Fine plants, well budded, $\$ 6.00$ per doz, $\$ 45.00$ per 100 .

\section{Bay Trees (Laurus Nobilis).}

We were awarded GOLD MEDAL, Mighest Award,

For Our Exhibit of Bay Trees at the Pan-American Exhibition. Buffalo, 1901

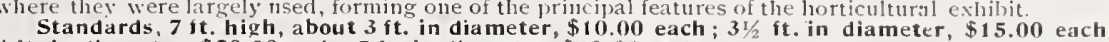

\section{Boxwood.}

There is a large demand for these heatifnl decorative plants. They nake beatutinl specinlens, rees. They are not only used as decorative plants for the sdme purpose as bay: trees, but

Pyramids, 3 it. high, $\$ 2.00$ each; $31 / 2 \mathrm{ft}$ high, $\$ 2.50$ each; $4 \mathrm{ft}$. high, $\$ 3.50$ each

Standard, or tree, heads about $1 \frac{1}{2} \mathrm{ft}$, in diameter, $\$ 2.00$ each ; $2 \mathrm{ft}$. in diameter, $\$ 3.00$ each.

\section{Hydrangea Hortensis Rosea.}

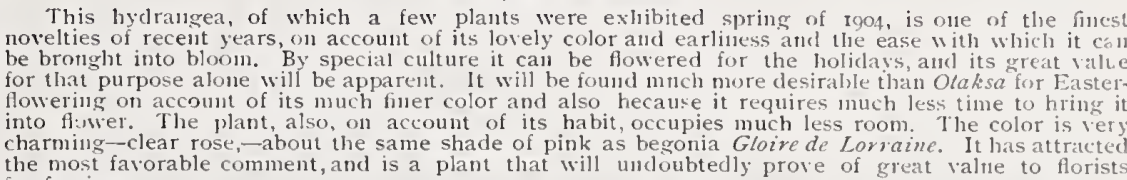

Extra strong pot-grown plants ready for forcing or for stock, three to four branches, $\$ 1.00$ each.
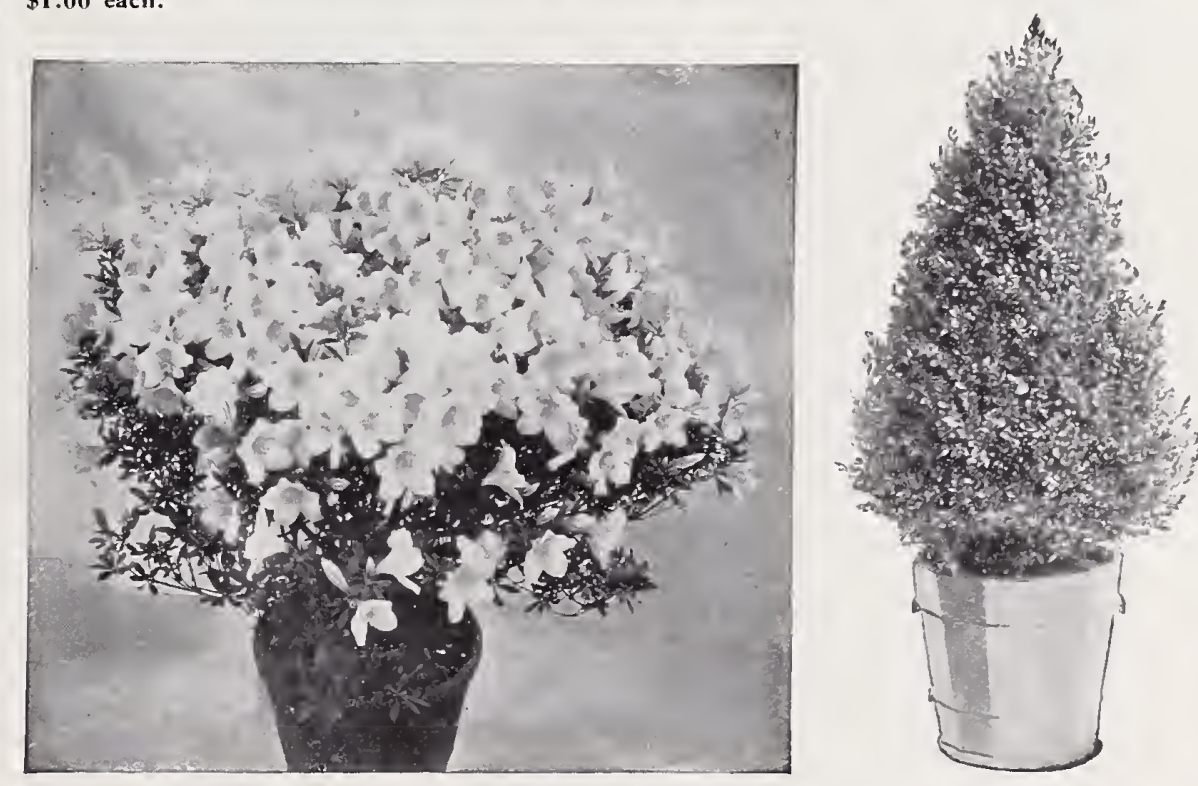

Novelties in Carnations for 1905

Fiancee $-A$ record-breaking carnation. Flower is innenes rgo4. it was awarded the Lawison Gold Medal for the hest hundred blooms any variety A

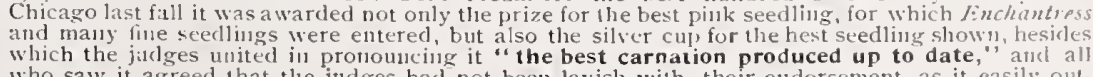
who saw it agreed that the jndges had not been lavish with their endorsement. as it

Cardinal. This fine new scarlet carnation was awardecl the first prize at the D prove very valnable. \$12.00 per $100 . \$ 100.00$ pir 1,000

Fred. Burki. $\$ 100.00$ per 1,000 . 


\section{CARNATIONS FOR}

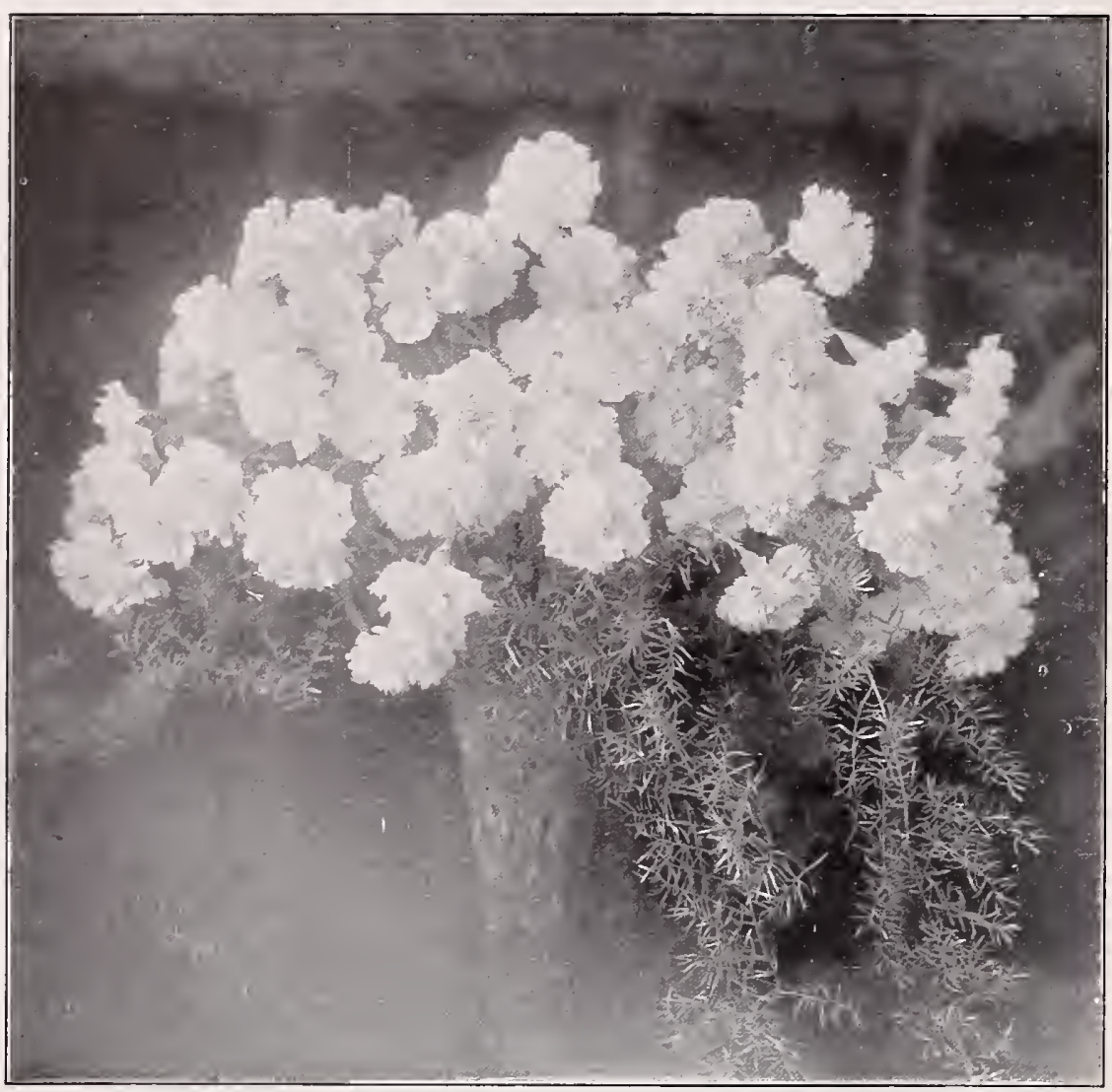

Mrs. M. A. PATTEN.

This is the finest variegated carnation ever introduced and for value and beauty is in the Enchantress
and Lazoson class. It will supersede $M T r$ s. George $M I$. Biradt, as it will outbloom that variety two to one, and has a much longer and better stem. giving fine long stems very early in the season. It is a very vigorous grower and the habit of the plant is ideal. The flowers are of the largest size- three to three
and a half inches in diameter-and very fraprant. The ground color is pure white, beautifully narked
with pink-just ellough to make the flower chaste and attractive.

$\$ 3.00$ per dozen, $\$ 20.00$ per 100 .

\section{DA H EIM.}

This is a wonderful improvement over any other crimson carnation in cultivation to-day. The flowers are of mammoth size, averaging fully three and one-half inches in diameter, of splendid shape, compact, well built up in the centre, and possessing magnificent keeping qualities. It never
shows the slightest tendency to go to sleep. The color is that desirable shade of crimson called the cimson, slightly shaded with maroon-wonderfully brilliant in the sunlight or artificial The labit of the are also very fragrant, having a decidedly strong clove fragrance.

Lawson; in fact, it might be called a crimson Lazuson, as it has all the characteristics of that variety as far as freedom of flowering, habit of growth, foliage, etc., are concerned. It has a grand stiff stem, holding the flowers perfectly erect, the caly never bursts, it is a very free and abundant bloomer and
develops very quickly. We know of nothing in crimson carnations that approaches this in any way, and $\$ 2.50$ per dozen, \$16.00 per 100 .

\section{WINTER-FLOWERING.}

Enchantress (The Queen of Carnations).-This is truly a queen a mong carnations, on account tinuous blooming habit. The color is magnificent-a beautiful shade of light silvery pink, deepening toward the centre-a Daybrak color. Besides its beautiful and desirable color, the flower is
enormous-t hree and a-half to four inches in diameter, when fully developed measuring four inclies. The enormous blooms are borne on stiff stems two to three feet in length, which hold the flowers perfectly erect. It is a very early, free, and continuous bloomer, an ideal grower, very healthy, and of vigorous constitution. It needs no special culture to develop its magnificeit blooms

White Bradt. - Similar, except color, to Mrs. George M. Bradt, from which it is a sport. Harlowarden. - Flowers very large, bright crimson. An unusually strong grower with very The Queen. - An exceedingly free-blooming white carnation. A rival of Boston Market as a Above four sorts, $\$ 2.00$ per dozen, $\$ 12.00$ per 100 .

Mrs. Thomas W. Lawson. - Deep cerise-pink. By far the best dark pink carnation, Grown more largely than aly other one carnation.

Boston Market. - For an everyday bread-and-butter white carnation, plant Boston Market. early, free, and continuous blooming. Will produce more per square foot than any other standard
white sort. Fine large flowers two and a-half to three inches in diameter, with fine stiff stems. Prosperity. - Not surpassed by any other variety for beauty or size. An immense flower, white, Mrs, George MI. Bradt. - Clear white, heavily edged and striped with bright scarlet. J. H. Manley - The best and most profitable of the older scarlet varieties. An cxceedingly Harry Fenn. - We consider this the very best of the older crimsons. An exceedingly free Above six sorts, $\$ 8.00$ per 100 .

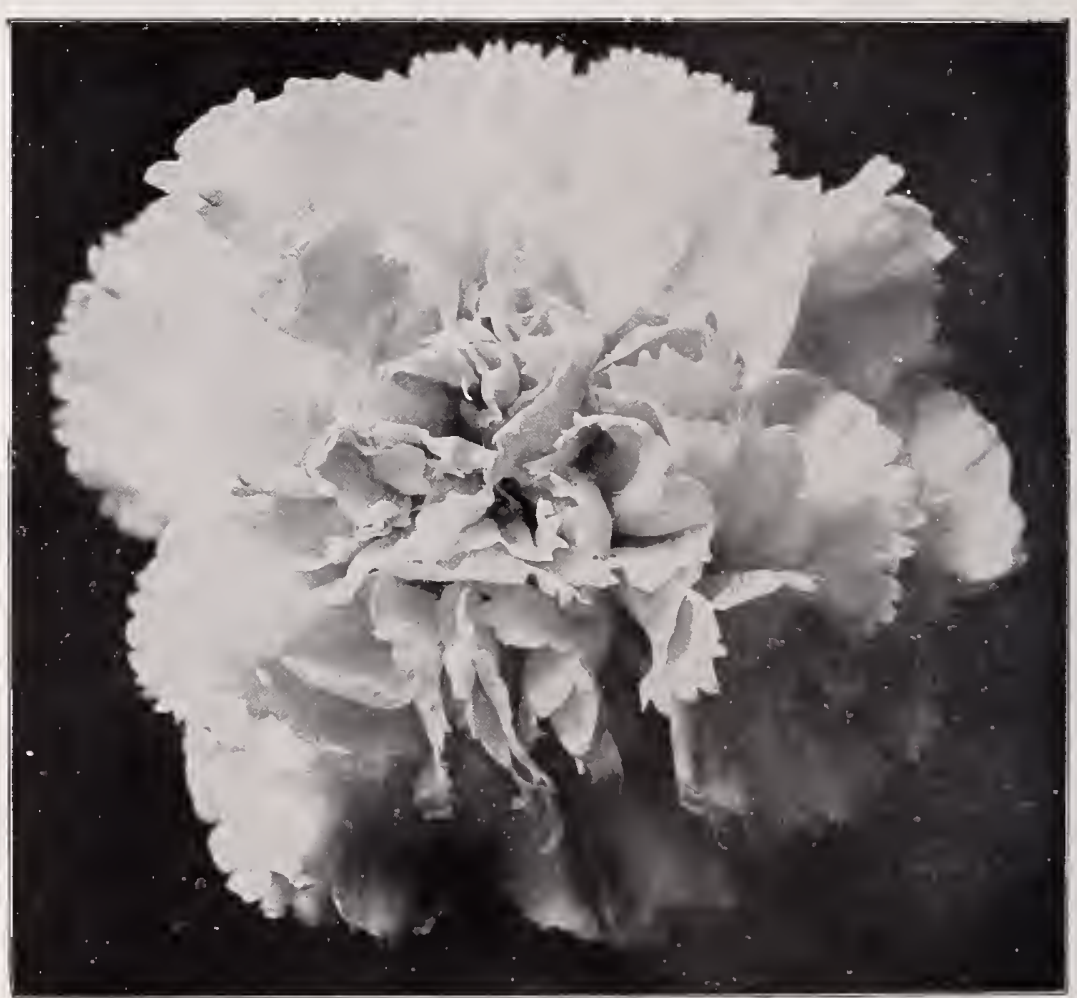

Enchantress. The QueEn of Carnations. (Actual size ol flower.)

$\$ 6.00$ per 100 .

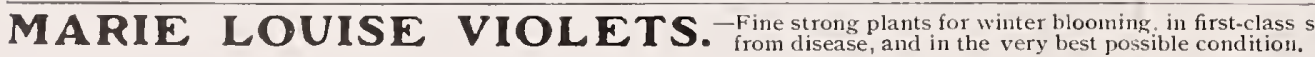




\section{PALMS AND OTHER DECORATIVE PLANTS}

We desire to call partlcular attention to the fact that our palms are not forced in high temperatures, but are grown cool. Most of our stock is grown out of doors all summer in lath houses, so that it is very hardy, and will give much better satisfaction than stock that has been forced and grown in high temperatures.

We should be very glad to have customers visit our Scarborough Nurseries, where our palms are grown, and examine our stoch and make their own selection. Where this is not convenient, orders sent by mail will recelve personal and careful attention, and we will guarantee perfect satisfaction.

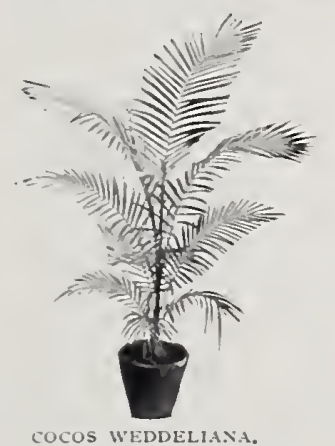

\section{COCOS WEDDELIANA.}

This dainty little palm makes a fine table plant, and is largely used for the Fine plants, $3-$ in. pots, $\$ \mathbf{\$ 3} .00$ per dozen.
Fint of fern pans,

\section{CYCAS REVOLUTA (Sago Palm).}

This is one of the most satisfactory house plants on account of its hardiness, and fiorists will find it one of the most salable palms. It is difficult to give length of leaves. If customers will name price they wish to pay, they can rely $50 \mathrm{c} ., 75 \mathrm{c} ., \$ 1.00, \$ 1.50, \$ 2.00$ each and up.
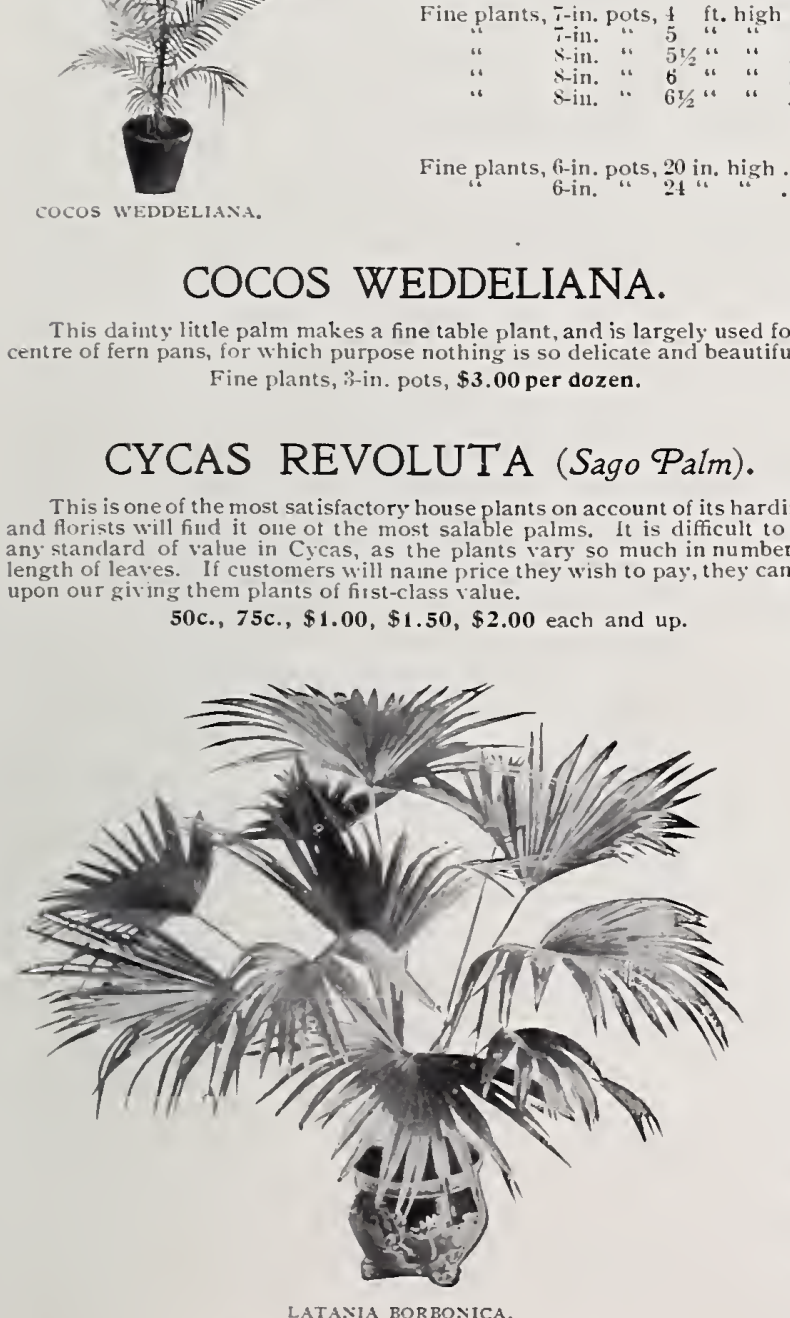

Fine plants, (6-in. pots, ${ }_{2+}^{20}$ in. high $\ldots$

\section{KENTIAS.}

We have a fine stock of this popular palm-undoubtedly the most popular of all palms for house purposes, on We can give particularly good value in the large sizes offered. We should like to emphasize the fact that

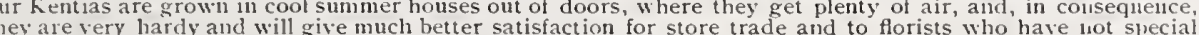
FORSTERIANA.

BELMOREANA.

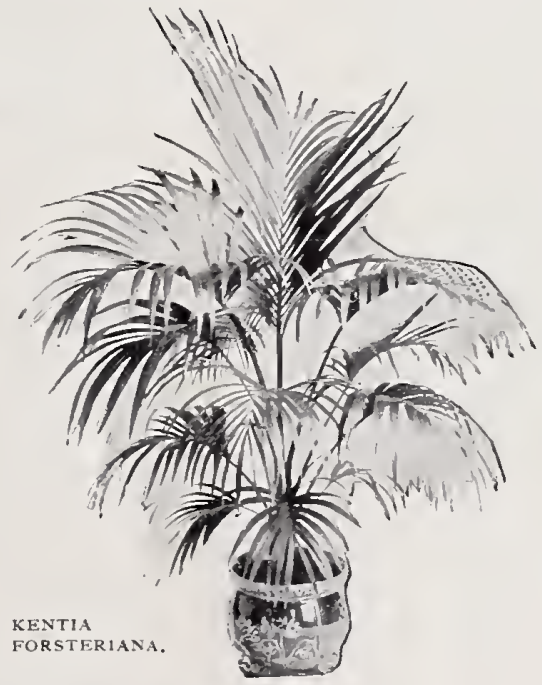

$\$ 4.00$ each
5.00
6.00
7.50
10.00
$\$ 1.00$ each

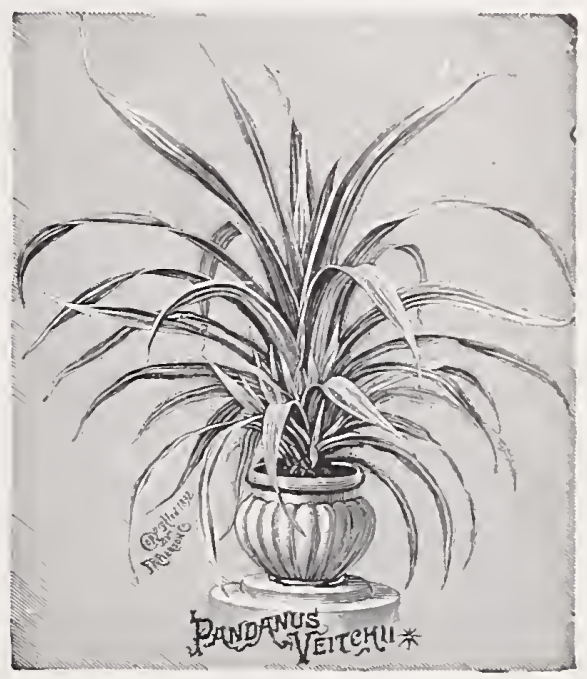

PANDANUS VEITCHII. We have a fine stock of this elegant decorative plant-one of the most
useful and beautiful ornamental house plants. Our plants have been grown cool, and are well colored.

PANDANUS UTILIS.

strong plants, 7 -in pots, 20 in. hight. $\$ 1.50$ each.

PHENIX RECLINATA.

Very hardy. Can be grown in a low temperature, for which resson

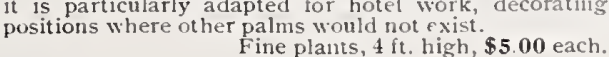

LATANIA BORBONICA (Fan-Leaf $P_{a} l m$ ). This is one of the most popular and reliable hardy palms for inevery respect. We offer a fine lot of medium and large sized plants. Florists will find the largest sizesofered rery

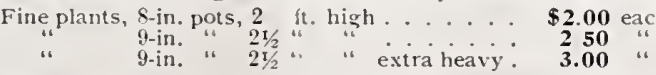

ASPIDISTRA LURIDA VARIEGATA. whis is the most durable plant grown for indoor decoration. It many other plants. It flourishes in sunshine or shade, does not mind dust or dry air, and can stand a good deal of cold.
Fine plants, 7 -in. pots, well colored. $\$ \mathbf{1 . 5 0 , \$ 2 . 0 0}$, and $\$ \mathbf{2 . 5 0}$ each

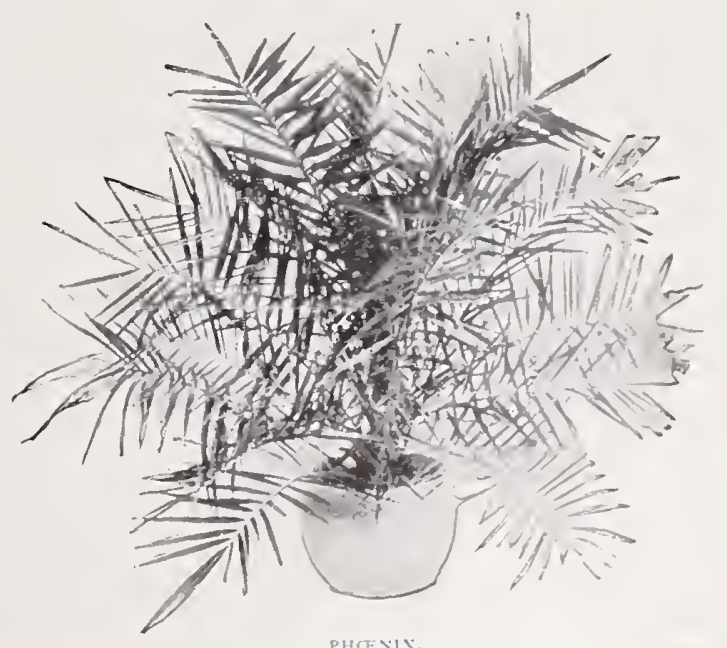

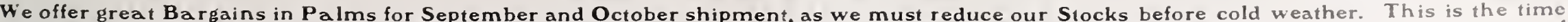

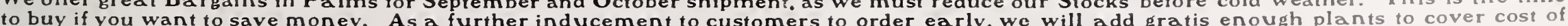
freight charges on all shipments made in September and October. 


\section{Nephrolepis Scottii. \\ New Dwarf, Compact Boston Fern.}

This is a sport from the well-known Boston Fern. and is a novelty that will commend itself to the liade.

Strong plants, 21 -in. pots, $\$ 4.00$ per doz, $\$ 25.00$ per $\mathbf{1 0 0}, \$ 200.00$ per $\mathbf{1}, \mathbf{0 0 0}$.
Extra strong plants, f-in, pots, $\$ 1.00$ each

Large specimen plants, 6 -in. pots, $\$ \mathbf{2} . \mathbf{0 0}$ each; ; 8 -in. pots, $\$ 3.50$ each ; 10 -in. pots, $\$ \mathbf{5 . 0 0}$ each.

\section{Adiantum Croweanum.}

This fine Adiantun originated with Mr. Peter Crowe, and has been held by him until this time for his own use for growing for the cut flower market on account of its exceptional value and the great profit tlat tire place to it for some time, as it has paid him better than any other crop that he could grow. $\mathrm{As}$ grown by him, the stems are twice as long and the fronds twice as large as the best Adjaantum cuneatum that we have e er seen. Mir. Crowe has finally concluded to place it on the market, and in undoulced
great demand and meet with a large sale, as its value is well established and well understoo

It has brought twice the price of A Alantum cunealum, on account of its much longer stems and larger "uneatum, the fronds are much hardier, and can be kept longer. The leaf stalks grow eighieen inches or more in height, with large fronds. The fact that it lias brought twice
the price of cuneatum in the cut flower market will he the bcst the price of cuneatum in the cut flower market will he the bist
index of its value. Those who have a inarket for Adiantum and index of its value. Those who have a inarket for Adiantum and
want something superior, will find this much more profitable tlaan Strong plants, suitable for 4 -in. pots or for benching, $\$ 5.00$ per
dozen $\$ 35.00$ per $100, \$ 250.00$
per 1,000 dozenl. $\$ 35.00$ per $100, \$ 250.00$ per 1,000 .
Stock plants, iromi bench, requiring 8 to 10 -in. pots, $\$ 9.00$ per dozcn.

FICUS ELASTICA (Rubber Plant). This certainly is one of the best plants grown for decorative purposes. We have a grand stock. Plants are grown trom top cuttings,
and have large, perfert, full-sized leaves right to the pot, and are in
grtand shape Strong plants, 4 -in. pots, 10 to 12 in. high, $\$ \mathbf{3 . 0 0}$ per dozent.

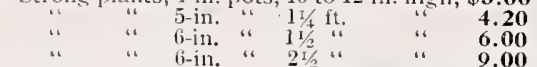

The larger sized plants offered below will be found very useful for They are splendid for hotels aulpose where large plants are desirable. at a moderate cost are cesired. Plants are very bushy, and are very heap at the prices at which they are offered,
l.arge bushy specinens, 12 -111. pots. $31 / 2$ ft. high, $\$ \mathbf{3 . 0 0}$ each.

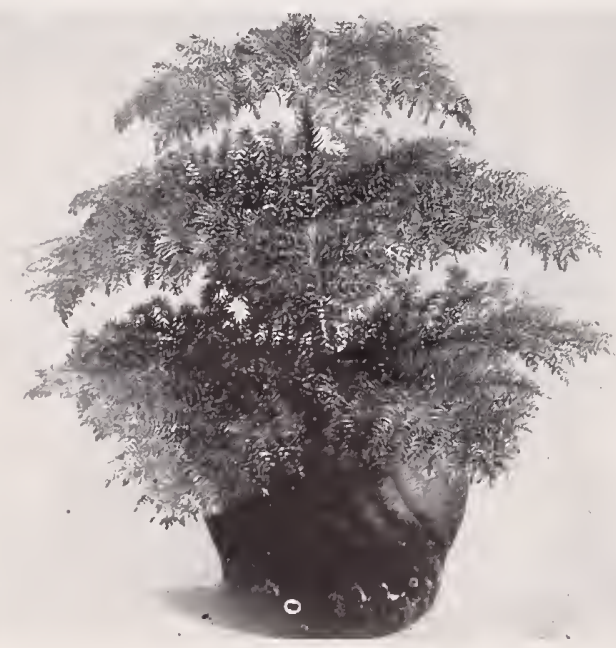

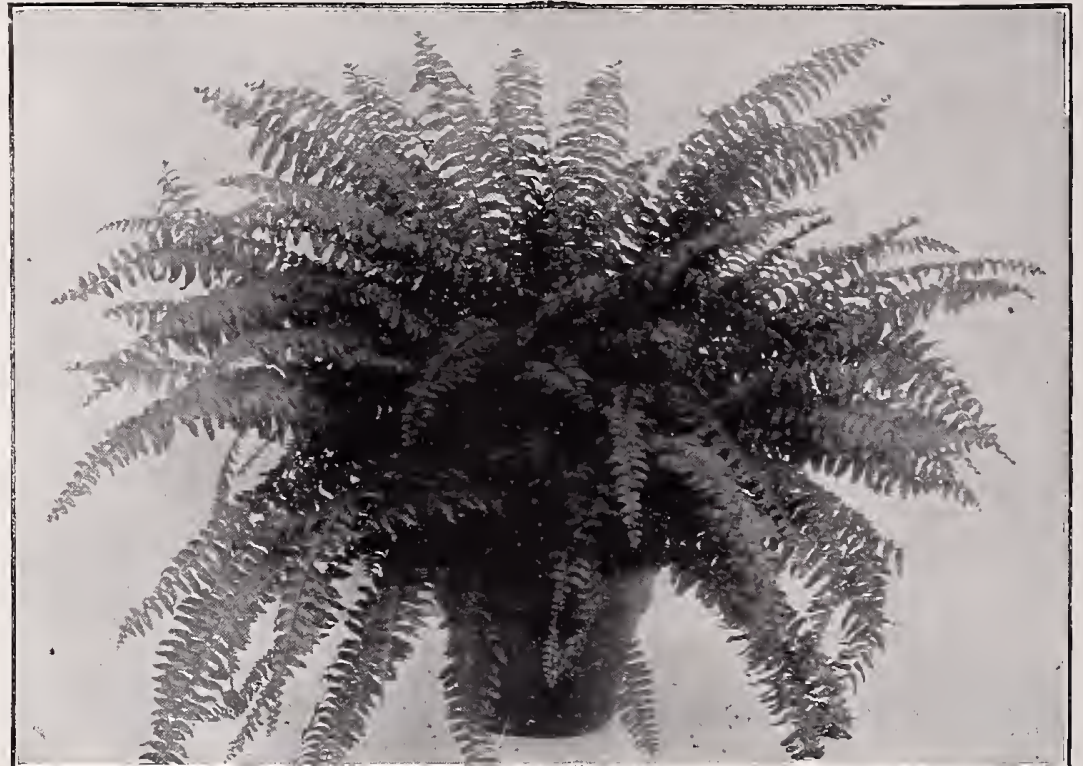

NEPHROLEPIS SCOTTII, IN A SIN-LNCH PAN.

\section{ASPARAGUS SPRENGERI.}

This has now become very popular, and is exceedingly valuable for growing for cutting for foliage. No other green that can be grown is so fine, especially to use with carnations. It grows rapidly: tion, and when grown in large sizes, say 6 -inch pots or larger, makes one of the finest and most

salable house plants. $\quad$ Extra strong plants, $2 \frac{1}{2}-$-in. pots, $\$ \mathbf{4} .00$ per 100 .

\section{ASPARAGUS PLUMOSUS NANUS.}

One of the most profitable and useful plants now grown; as easily grown as Smilax, of which it has largely taken the place, as it is very much more beautiful and desirable in every way: It is grand when grown in long strings, ancl also makes a very useful pot plant.

\section{SMALL FERNS FOR FERN PANS.}

The use of ferneries as ornaments for the dimner table is now amost universal. uffer a nice stock of the hardiest varieites, a good collection of the best sorts.

\section{ARAUCARIAS.}

Small plants grown in pots are most desirable for table and decorative purposes genExcelsa -Norfolk Island Pine. This is the variety that has become so popular fo Fine plants, about 15 in. high $\$ 1.00$ each

$$
\begin{array}{rr}
20 & \text { " } \\
30 & \mathbf{2 . 5 0}
\end{array}
$$

Glauca. - A more compact grower than Excelsa. The fronds are longer, broader, and Fine plants, about 15 in. high, $\$ 1.50$ each.

Compacta. - The finest variety that has ever been introduced superior to Excelsa Fine plants, about $15 \mathrm{in}$, high, $\$ \mathbf{2 . 0 0}$ eacls.

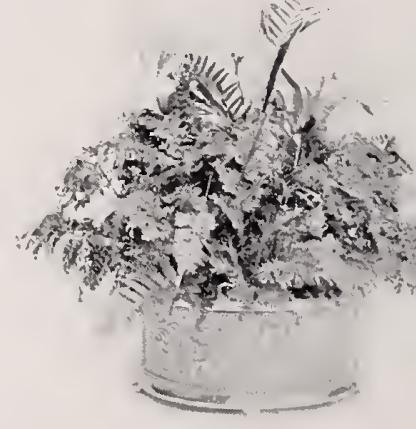

Buyduring September and October, when plants can be shipped with perfect safety by freight, saving express charges later in the season. Remember $5 \%$ can be deducted from all prices in this catalogue when cash accompanies order. 


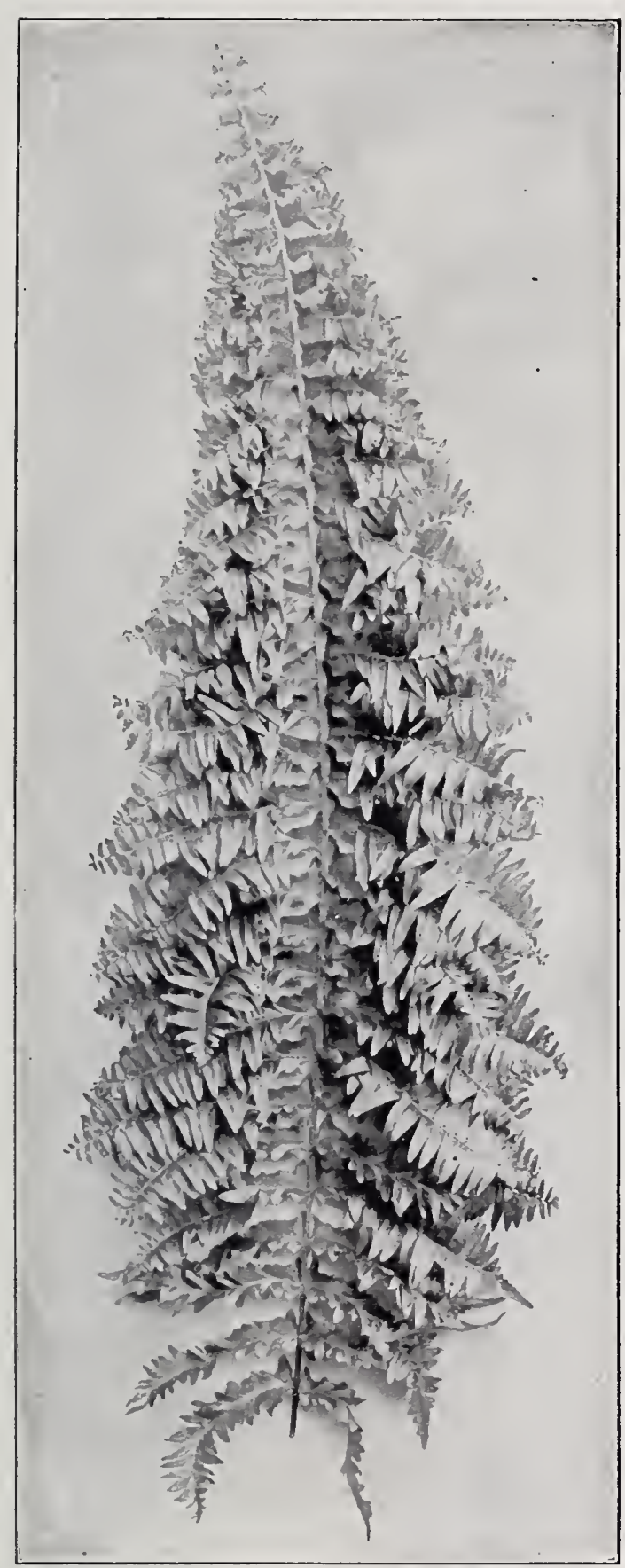

PHOTOGRAPH OF A FROND OF NEPHROLEPIS PIERSONI Shoving how the pinne divide, making miniature fronds.

\section{THE PIERSON FERN NEPHROLEPIS PIERSONI}

This wonderful new fern, which has attr
by us in spring of 1903 , has been pronounced

The Most Notable Introduction in Decorative Ferns since Adiantum Farleyense

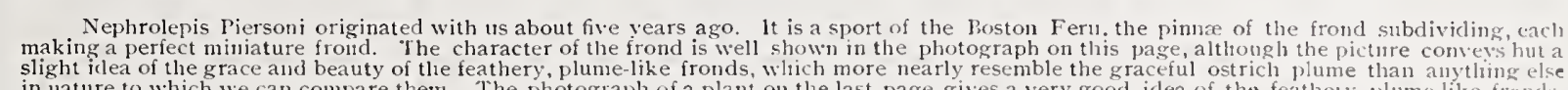

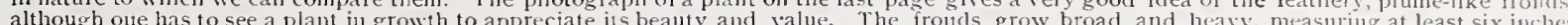
across when fully developed, increasing in heauty as they develop. On account of the weight of the foliage, the plant assumes an exceedlingly graceful appearance, and, owing to the fullness of the fronds, even small plants are well furnisherl, making much more symmetrical and beautitu!
plants than the Boston Fern. The divided pinn ends beittg a light green, while the cents

The Most Valuable Novelty Introduced in Many Years.

It is wonderfully valuahle. not only on account of its beauty, but also on account of its ease of culture, hardiness, ancl general arlaptabilit It has all the free-growing, hardy characteristics of the Boston Fern, and, like that plant, is equally suitable for house culture ancl a much mo beautiful plant for greenhouse ancl conservatory decoration; in fact, it is a plant that appeals to every one, ancl on that account will
more valuable and profitable plant than the Boston Fern, which has had the most phenomenal sale of any decorative plant that ha grown, but which cannot be compared to Nephrolepis Piersoni for beauty and general effectiveness. Fvery one who has seen it is charmed witl? original variety (the Boston Fern) that there is positively no comparison to he made." We consider it the most valuable novelly thal has been introduced in many, many years.

Besides its value as a decorative plant, it is very valuahle for citting to use with cut flowers. There is nothing more
tory in boxes of assorted flowers, and the handsome fronds can also be used very effectively in the finest tahle decoration.

The following flattering endorsement received from the Society of American Florists at the Milwaukee Convention, August, I9:5-a jear

Another Gold Medal Award.

"F. R. Pierson Compan, Tarrytown-on-Hudson, $\mathrm{N}$. Y., showed a magnificent lot of Nephrolepis Piersoni, which was awarcled the gold
medal of this Society at Ashevile in 1902 . As it has already received the highest possihle award in the gift of the Society of American Florists,

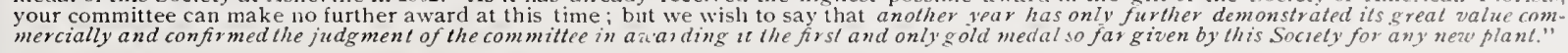

\section{A Eew Hints Regarding Culture.}

This fern is an exceelingly strong grower, and in order to perfectly develop, the beauty of its broad, heavy fronds, it should be grown in very light houses, with practically no shade, and shorld be given plenty of air. It should be grown a little

grows fastest and best when planted out on benches, and should be givell plenty of room to develop. Aiter the plants have attained the reguirei size they should be lifted from the bench early in the fall and estabished in pots for a month or tho before selling time. close together and in a dark house, the plants will not develop perfectly. and will uot give the satisfaction that they otherwise won most beautiful fern. We find the beautiful speciments which wee handle the most profitahle and readily salable plants that we have ever sold, and anyone who gives it the proper treatment cannot fail to be pleased with it.

Greatly Reduced Prices this Season.

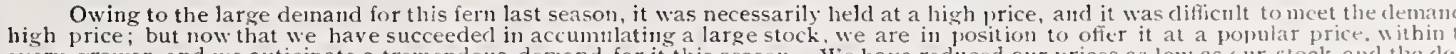
we anticipate will permit. and any offers for less money will unquestionably he at the experse of quality.

this heavy established stock from $21 / 4$-inch pots much better value and much clieaper than runners from the hench at any

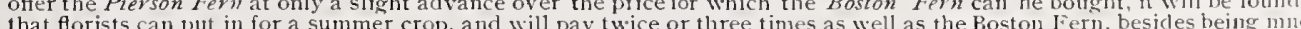

of its beauty and scarcity. Strong plants, $21 / 4$ inch pots, $\$ 6.00$ per $100, \$ 50.00$ per 1,000 .

\section{Large Specimen Plants.}

We desire to call particular sttention to on large stock of specimen plants ready for immediate pot-grown plants in the rery best possible condition- not plants overpotted or linted from the
offered. Stock is in grand shape, and we will guarantee that every shipment will give perfect money on these large plants for immed are sale, but by shifting the plants into larer sons and holding the Fine plants, 5-inch pots, 35c. each; extra fine piants, 6 -inch pots, 50c. each.
that they can handle.
Fine specimens, $8=i t \ldots$ pots, $\$ 1.00$ each; extra fine specimens, 10 inch pots, $\$ 2.00$ each. 


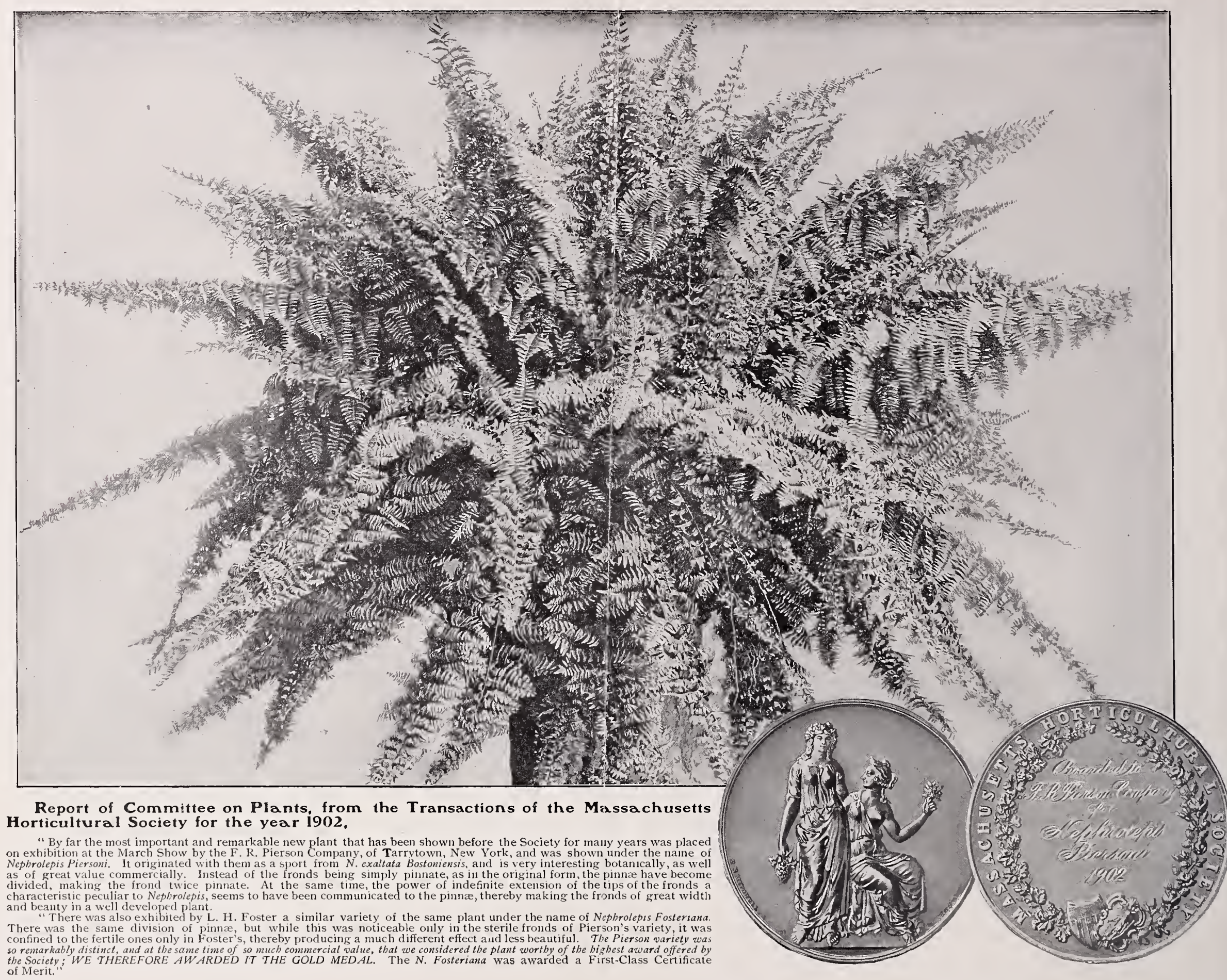

